\title{
LAS CONSECUENCIAS DE LA INFRACCIÓN DE DEBERES MATRIMONIALES NO DAN LUGAR A INDEMNIZACIÓN
}

THE CONSEQUENCES

OF THE INFRINGEMENT OF MARRIAGE DUTIES DO NOT GIVE RISE TO LIABILITY FOR DAMAGES

Gabriel Hernández Paulsen*

\section{RESUMEN}

Conforme a nuestra normativa y jurisprudencia, las consecuencias de la infracción de deberes conyugales no deben indemnizarse. Esto se de debe a que no son obligaciones; el derecho establece efectos especiales ante su vulneración; la protección de los derechos fundamentales de los cónyuges se opone al resarcimiento; y hay enormes dificultades para evaluar los requisitos de la responsabilidad civil en estos supuestos.

Palabras clave: Deberes conyugales, responsabilidad civil.

\section{AbStRact}

In accordance with our rules and jurisprudence, the consequences of the breach of marital duties shall not be compensated, as they are not obligations. Additionally, Law establishes special effects in this case, the protection of fundamental rights of the spouses is opposed to compensation and there are huge difficulties to assess the requirements of civil liability.

Keywords: marital duties, civil liability.

* Profesor de Derecho Civil Universidad de Chile. Doctor en Derecho Privado Universidad Autónoma de Barcelona. Máster Oficial en Derecho Empresarial Universidad Autónoma de Barcelona. Magíster en Derecho mención Derecho Público Universidad de Chile. Dirección postal: Pío Nono 1, Providencia, Santiago, Chile. Correo electrónico: ghernan@derecho.uchile.cl. Artículo recibido el 27 de julio de 2016 y aceptado para su publicación el 11 de agosto de 2016. 


\section{INTRODUCCIÓN}

Uno de los problemas mayormente debatido en el derecho de familia contemporáneo es el de la procedencia de indemnización por los daños extrapatrimoniales o morales ocasionados por o contra una persona cuando su condición de integrante de una familia resulta relevante ${ }^{1}$. Se trata de una temática de desarrollo relativamente reciente ${ }^{2}$, que, conforme a la opinión de la doctrina, puede enfocarse desde dos perspectivas: una externa y otra interna ${ }^{3}$.

La perspectiva externa del asunto está representada, por una parte, por los detrimentos causados por un miembro de una familia, cuando esta condición resulta relevante, a un individuo que no forma parte de ella; y, por otra, por los ocasionados por un tercero a uno de dichos miembros, cuando esta condición resulta relevante 4 . Ejemplo de los primeros son los ocasionados a una persona por un hijo incapaz ${ }^{5}$ o por un individuo casado en sociedad conyugal ${ }^{6}$. Entre los segundos, merecen mención los provocados a los progenitores por el fallecimiento de su hijo a consecuencia de la conducta de un tercero ${ }^{7} ; \mathrm{y}$, en algunos ordenamientos, los generados por el nacimiento de un hijo gravemente enfermo cuando haya habido negligencia en el diagnóstico de la respectiva patología y obstaculización del derecho a abortar ${ }^{8}$. Según puede apreciarse, se trata de supuestos indemnizatorios encasillables en los casos generales de responsabilidad civil al ser hipótesis en que hay lugar a la indemnización bajo los presupuestos típicos que la hacen procedente, sin que se tenga en cuenta la calidad de miembro de una familia del victimario o la víctima.

La perspectiva interna de la cuestión está referida a los detrimentos causados a uno de los miembros de una familia por otro. Estas son las hipótesis que presentan peculiaridades a tener en cuenta en este trabajo ${ }^{9}$. Dentro de

${ }^{1}$ Me he referido antes a esta cuestión en términos generales en Hernández (2008).

${ }^{2}$ Lo constatan para el caso de nuestro derecho, Severín (2008 a), p. 110 y Bravo (2015), p. 249; para el del europeo, Roca (2000), p. 533; y, para el del español, Romero (2009), p. 39; y Sáinz-Cantero y Pérez (2012), p. 1. Acerca de la jurisprudencia nacional sobre este asunto, véanse Corral (2014) y VARGAS (2014).

${ }^{3}$ Lepín (2014), p. 399; Medina (2008), pp. 41-44.

${ }^{4}$ Medina (2008), pp. 42s.

${ }^{5}$ Barros (2006), pp. 174-180; Gómez (2002), pp. 1033-1071.

${ }^{6}$ El Código Civil se refiere a estos supuestos y varios otros similares. Véase la nota 56.

${ }^{7}$ Barros (2006), pp. 345ss.

${ }^{8}$ En estos casos el daño alegado es el nacimiento. Se trata del llamado wrongful birth (perjuicio de nacer), en que los progenitores demandan al médico por el daño sufrido a consecuencia del nacimiento de un hijo enfermo. También pertenecen a esta familia los supuestos de nacimientos no deseados por fallo en el mecanismo anticonceptivo prescrito. Estas hipótesis se distinguen del denominado wrongful life (perjuicio de vivir), en que es el hijo nacido en tal circunstancia quien demanda al médico. BARros (2006), pp. 365ss.; De la MaZa (2014), pp. 307-330; Medina (2008), pp. 531ss.

${ }^{9}$ Respecto de la perspectiva interna, véase Medina (2008), pp. 41-44. 
estos daños se distinguen los generales y los específicos. Los primeros son aquellos que, sin perjuicio de acontecer entre familiares, pueden tener lugar en cualquier ámbito relacional, de manera que, llegado el caso, su resarcimiento procede con independencia de la concreta condición del victimario o la víctima. Es el caso, v. gr., de los detrimentos a la salud o a la integridad física o psíquica (malos tratos, transmisión de enfermedades venéreas, etc.), al honor (injurias, calumnias, etc.) o a la intimidad (interceptación de comunicaciones, revisión de correspondencia, etc.). Los segundos son aquellos que implican una vulneración de intereses protegidos en particular por el derecho de familia. Pueden mencionarse, a modo de ejemplo, los derivados del no reconocimiento de un hijo ${ }^{10}$, de la deficiente administración de la sociedad conyugal, de la ocultación de paternidad y de la obstaculización del régimen de cuidado personal o del comunicacional ${ }^{11}$.

Existe amplio consenso en que la regla general es que procede responsabilidad civil ante la ocurrencia de menoscabos causados entre familiares. Se trata de una conclusión que es el corolario del principio según el cual todo daño jurídicamente relevante debe ser indemnizado, cualquiera sea el ámbito en que acontezca, así como quienes sean el dañador o la vícti$\mathrm{ma}^{12}$. De esta forma, contrariamente a lo postulado en alguna época, es doctrina asentada en este terreno que no caben inmunidades o privilegios derivados de las particularidades de la vida familiar. Estas inmunidades se construyeron en determinado momento -esgrimiendo la primacía del interés supraindividual sobre el personal- con base en la idea de que la procedencia de responsabilidad civil por los daños causados entre familiares podría implicar un atentado a la intimidad o la armonía familiar o a los vínculos de solidaridad y altruismo que deberían regir en esta esfera ${ }^{13}$.

${ }^{10}$ Pizarro (2014) passim.

${ }^{11}$ Sáinz-Cantero y Pérez (2012), pp. 23ss.; Sambrizzi (2001), pp. 160-165; Lepín (2014), p. 400; ZAMBRANO (2014), pp. 41 ss.

${ }^{12}$ Sáinz-Cantero y Pérez (2012), p. 1.

${ }^{13}$ Ferrer (2001), p. 3; Vargas (2009), pp. 115-124; Marín (2006 b), p. 148; Mendoza (2011), pp. 43s.; Medina (2008), pp. 19ss.; SÁinZ-CANTERo y Pérez (2012), pp. 3s. En relación con el régimen de inmunidades suele distinguirse entre los dos grandes sistemas de derecho occidental. El sistema de derecho codificado (Civil Law) obró tradicionalmente sobre la base de no establecer inmunidades o privilegios en materia de daños entre familiares, rigiéndose por las reglas generales de la responsabilidad civil (Francia, Italia, España y Chile, por ejemplo). El derecho alemán representa una notable excepción, ya que los parágrafos 1359 y 1664 del $B G B$ limitan la responsabilidad entre cónyuges y entre progenitores e hijos a los daños causados con dolo o culpa grave. En todo caso, en los ordenamientos jurídicos pertenecientes a este sistema los tribunales suelen restringir la operatividad de la responsabilidad civil entre parientes haciendo una aplicación reflexiva de sus requisitos de procedencia, destacadamente del daño, la culpabilidad y la causalidad. En el Common Law, históricamente se establecieron reglas generales de inmunidad o privilegio en materia de daños entre familiares (llamadas, en general, excepciones de domestic relations y, para 
Considerando que la familia ha dejado de ser el ámbito de lo privado inexpugnable, para regirse plenamente por el respeto a los valores y principios del Estado democrático de derecho y, sobre todo, a los derechos humanos, el abandono de las tesis de la inmunidad aparece como el lógico corolario de la primacía de dichos valores y principios ${ }^{14}$.

Lo anterior ha redundado en que la solución que se impone hoy en materia de detrimentos ocasionados entre familiares es la que postula, como regla general, su resarcimiento, en aras de la plena protección de los derechos individuales de los miembros de la familia, que priman sobre la salvaguarda de esta ${ }^{15}$. Así, las víctimas de un detrimento deben ser indemnizadas tanto cuando el daño se ha producido en la esfera de su vida social o negocial, como cuando ha acontecido en la de su vida íntima y, más específicamente, en la familiar; con independencia de quien sea el dañador ${ }^{16}$. En todo caso, en el interior de esta tesis conviven importantes discrepancias, existiendo posturas que aceptan la procedencia del resarcimiento en términos amplios y otras que lo hacen de forma restringida ${ }^{17}$.

En lo que aquí importa y por lo que respecta a los menoscabos causados entre cónyuges, la aludida regla general se concreta en que debe proceder indemnización a favor de la víctima cuando la conducta dañosa constituye un delito o falta penal, un atropello a sus derechos humanos o, en general y englobando ambas posibilidades, una hipótesis de responsabilidad civil ${ }^{18}$.

el caso de los ocasionados entre cónyuges, interspousal inmunity), que implicaron su no indemnizabilidad. En Estados Unidos, la procedencia de estas inmunidades comenzó a decaer notablemente a partir de 1910, en virtud de la labor jurisprudencial, pasando por la Married Women's Act, hasta que el Restatement of Torts $2 d$. (1977) las eliminó definitivamente entre cónyuges, si bien reconoció que determinadas conductas podían verse afectas a una inmunidad en virtud de la particular relación existente entre los consortes. En Inglaterra, las inmunidades conyugales son completamente abolidas en 1962, con la Law Reform (Husband and Wife) Act, si bien se faculta al juez para suspender el pleito en caso de considerar que no producirá ningún beneficio sustancial a las partes. En síntesis, en la actualidad se constata un acercamiento entre ambos sistemas en esta materia, atendida la reflexiva dinámica implementada por los tribunales en el primero y la derogación de las inmunidades familiares en el segundo, sin perjuicio de la aplicación en este de una dinámica jurisprudencial similar a la del anterior. HERnÁNDEZ (2008), pp. 15s.; FERRER (2001), pp. 4-8; ROCA (2000), pp. 534s.; Zambrano (2014), pp. 18-21; Romero (2009), pp. 35-37; Sáinz-Cantero y Pérez (2012), pp. 2s.; Severín (2008 a), p. 112; LóPez de la CruZ (2010), pp. 5-9; Vargas (2009), pp. 107ss.

${ }^{14}$ López de la Cruz (2010), p. 9; De Verda y Chaparro (2012), pp. 105-107; Zambrano (2014), pp. 19-21.

${ }^{15}$ Marín (2006 b), pp. 147-149; Medina (2008), pp. 21ss.; Sáinz-Cantero y Pérez (2012), pp. $4-7$ y 10s.; FERRER (2001), pp. 3s.; VARGas (2009), p. 179

${ }^{16}$ Medina (2008), pp. 29ss.

${ }^{17}$ Los postulados y fundamentos de esta tesis pueden consultarse en SEverín (2008 a) pp. 117s.; Medina (2008), pp. 45ss.

${ }^{18}$ Tanto en general como en el derecho de familia basta, en orden a la procedencia de responsabilidad civil, con la lesión de un interés protegido jurídicamente, independien- 
Así, por ejemplo, procede indemnización a favor del cónyuge víctima por los daños causados por su consorte a su salud o a su integridad física o psíquica (v. gr., los provenientes de violencia doméstica, de la transmisión de una enfermedad venérea o de un accidente de tránsito ocasionado por una conducción descuidada ${ }^{19}$; a su indemnidad sexual, a su intimidad y a su honor. Esto se debe a que estas hipótesis pueden configurar supuestos de ilícito penal (lesiones, delitos sexuales, delitos contra la privacidad, injurias o calumnias, etc.) o un atentado a derechos fundamentales. $\mathrm{Al}$ margen de estos casos, procedería indemnización ante la configuración de supuestos de responsabilidad civil pura en que uno de los cónyuges daña al otro, por ejemplo, a consecuencia de la obstaculización del régimen de cuidado personal o del comunicacional ${ }^{20}$.

Según anticipara, existe consenso en que los daños provocados entre familiares y, en particular, entre cónyuges, deben indemnizarse. Pero el consenso se relaciona principalmente con los detrimentos producidos por la vulneración de intereses que van más allá de aquellos a que se refieren los deberes conyugales, sin que se extienda a la resarcibilidad de las consecuencias de la infracción de tales deberes ${ }^{21}$. El presente trabajo se centra en esta última cuestión ${ }^{22}$.

temente de si está configurado como un derecho subjetivo, por ejemplo, como un derecho fundamental. SÁinz-CANTERo y Pérez (2012), p. 231; TAPIA (2016), pp. 165s.

${ }^{19}$ Medina (2008), pp. 121ss. Respecto de la responsabilidad civil por violencia intrafamiliar -que es el ámbito en que más claramente surge la necesidad de indemnización en este terreno- véanse ZAIKOSKI (2015), principalmente las pp. 145ss.; BonILLA (2012), pp. 178ss.

${ }^{20}$ MARín (2006 a) pp. 179-201. En cuanto a los criterios para determinar el monto de la indemnización y a los tipos de daño en las relaciones de familia, véase SÁınz-CANTERo y Pérez (2012), pp. 223s. y 227ss., respectivamente.

${ }^{21}$ VARgas (2009), p. 179. En Pinto con Rojas (2014), la sentencia de la Corte de Apelaciones señala lo siguiente: "Décimo cuarto: Que, sin perjuicio de lo expuesto para fijar una posición general sobre la materia, se deberá precisar que, en todo caso la indemnización de perjuicios dentro del ámbito señalado, podría no ser aplicable para todas las causales de divorcio contempladas en el artículo 54 de la Ley de Matrimonio Civil, puesto que allí existen motivos que más bien constituyen incumplimiento a los denominados deberes matrimoniales, como la convivencia, el socorro, la fidelidad que caen en el ámbito del Derecho de Familia, de manera que en tales casos, el asunto es más bien discutible y habría que analizar el caso concreto, con todas sus circunstancias, pero de lo que no existe duda alguna, es que tal indemnización resulta del todo procedente cuando el motivo que dé lugar al divorcio afecta a la persona del otro cónyuge, independientemente si estaban o no unidos por el lazo matrimonial, como lo es, el atentado contra la vida o malos tratamientos graves contra la integridad física o psíquica del cónyuge víctima, cuyo es el caso de autos”. La sentencia está comentada en BRAVO (2015), pp. 253ss. Cabe tener en cuenta que las demandas indemnizatorias entre cónyuges se presentan, por regla generalísima, ante una crisis matrimonial (sobre todo, irreversible) y, más concretamente, en el contexto de una separación o un divorcio, ya que la vigencia de la vida conyugal desincentiva, en la mayor parte de los supuestos, la deducción de una acción indemnizatoria. Fleitas (2001), p. 174; Ferrer (2001), p. 3.

${ }^{22}$ Una cuestión vinculada que no abordaré es la de las perturbaciones generadas a un cónyuge por el divorcio en sí mismo, al margen de la causal que, en su caso, pueda 


\section{CONSECUENCIAS DE LA INFRACCIÓN}

DE DEBERES CONYUGALES

\section{Los deberes conyugales son aquellos que vinculan a quienes se encuentran unidos por matrimonio y caracterizan por su carácter personal y preemi- nente contenido ético o moral. \\ Dichos deberes están recogidos, principalmente, en los artículos 102, 131 y 133 del Código Civil. Entre ellos sobresalen los deberes de fidelidad o de guardarse $\mathrm{fe}^{23}$, cohabitación o de vivir en el hogar común ${ }^{24}$, socorro, ayuda mutua y respeto y protección recíprocos ${ }^{25}$.}

haberlo motivado. Existe en la doctrina una álgida discusión respecto a si, aparte de la indemnización por la respectiva causal (por ejemplo, malos tratos, infidelidad o abandono de hogar), deben resarcirse las consecuencias del divorcio en sí mismo (v. gr., la pérdida de estabilidad emocional y/o económica). En términos sintéticos, me inclino por su no resarcibilidad por ser producidas por el ejercicio legítimo de la acción para solicitar el divorcio. Véanse Fleitas (2001), pp. 185ss.; Medina (2008), pp. 45ss.; Sáinz-Cantero y Pérez (2012), 24s. y 79-81; SAmbrizzi (2001), pp. 133ss.; VARGAS (2009), pp. 299ss. En relación a esta cuestión la Corte Suprema, en Pinto con Rojas (2014), falló lo siguiente: "Séptimo: Cabe precisar que el daño que se indemniza no es el que ocasiona el divorcio en sí mismo, sino el menoscabo que proviene directamente del o los actos culpables generadores de responsabilidad extracontractual que los tribunales del grado tuvieron por legalmente establecidos en el proceso".

${ }^{23}$ Habitualmente entendido como impedimento para tener relaciones sexuales con alguien que no sea el cónyuge. Esta es su faceta negativa interpretada en términos restringidos. Existen tesis que lo amplían a una cara positiva, representada por el débito conyugal (deber de mantener relaciones sexuales entre los cónyuges), y extienden la negativa a evitar toda conducta que vaya contra la confianza que debe imperar entre los consortes (por ejemplo, no comunicarle al cónyuge la interrupción del uso de anticonceptivos o informarle falsamente de su uso). Una interpretación amplia de este deber en BARRIENTOS y Novales (2004), pp. 284 y 292; Zambrano (2014), pp. 29ss.; Marín (2006 b), pp. 150-52; Gil, Fama y Herrera (2006), p. 271. En contra, Mendoza (2011), p. 47. Respecto de las diversas interpretaciones en relación con él, véase Novales (2007), pp. 171-201. Si bien el Código Civil no lo define, podría acogerse una interpretación amplia sobre la base de que su artículo 131 se refiere en términos generales al deber de guardarse fe que pesa sobre los cónyuges y el 132, al adulterio como una "grave infracción al deber de fidelidad", con lo que estaría contemplando otras posibilidades de infidelidad. En todo caso, no cualquier atentado a dicho deber puede dar lugar al divorcio o la separación judicial por causales, ya que para que proceda el primero debe haber gravedady reiteración y, la segunda, gravedad (artículos 54.2 y 26 de la Ley $\mathrm{N}^{\circ} 19.947$, de 2004, respectivamente).

${ }^{24}$ Salvo que las circunstancias impongan otra cosa, como en el caso de las personas privadas de libertad, las que por trabajo no viven en él, las hospitalizadas y las que separadas no divorciadas. Respecto de este deber, véase Novales (2007), pp. 322ss.

${ }^{25}$ Un tratamiento de los deberes de socorro, ayuda mutua y respeto y protección recíprocos en Novales (2007), pp. 235ss. A los mencionados suele agregarse el que tienen los cónyuges de suministrarse auxilios para sus acciones y defensas judiciales. BARRIENTOS y Novales (2004), p. 292. 
Parte de la doctrina considera que las consecuencias de la infracción de deberes matrimoniales deben resarcirse ${ }^{26}$. Sus argumentos pueden sintetizarse en los siguientes: todo daño debe indemnizarse; la impunidad sería inconstitucional porque -en su caso- se tolerarían menoscabos a la integridad psíquica del cónyuge afectado; en las relaciones de familia se deben guardar mayores cuidados que en otras (por lo que no corresponde evaluar la conducta de los cónyuges de manera más laxa que respecto de otros individuos, ni siquiera en situaciones de crisis); los deberes matrimoniales son obligaciones (y los daños derivados del incumplimiento de ellas deben resarcirse); la prescripción de consecuencias específicas por el derecho de familia ante la referida infracción no implica descartar la aplicación de las reglas generales de la responsabilidad civil ${ }^{27}$.

En el interior de la aludida tesis, a su vez, existen divergencias entre los autores, que están referidas principalmente al factor de imputación de responsabilidad y al estatuto aplicable. En relación con el primero, si bien la generalidad opina a favor de la indemnización en caso de dolo, discrepan respecto del grado de culpa desencadenante de resarcimiento, ya que mientras para algunos el dañador debe responder por culpa leve y grave, para otros, solo debe hacerlo por esta última ${ }^{28}$. Respecto del segundo aspecto, para algunos la responsabilidad civil por infracción de deberes conyugales debe regirse por las normas del régimen contractual, por entender que el matrimonio es un contrato o un "negocio jurídico del derecho de familia", ya que aquel es el régimen general aplicable al incumplimiento de obligaciones preexistentes ${ }^{29}$; mientras que, para otros, debe hacerlo por el aquiliano, por entender que el matrimonio no es un contrato (sino un "negocio jurídico del derecho de familia") y que el régimen general de responsabilidad es el estatuto extracontractual,

${ }^{26}$ Herane (2007), p. 193; Marín (2006 b); Medina (2008), especialmente, pp. 45-71; Opazo (2012), pp. 595ss.; Novales (2007), pp. 117ss.; Vargas (2009), pp. 221ss. En la jurisprudencia, puede consultarse la sentencia de la Corte de Apelaciones de Talca dictada en Abarca con González (2012), que señala que “(...) seguimos a la doctrina comparada que sobre el particular se inclina mayoritariamente por la posibilidad de indemnizar los daños y perjuicios que se produzcan por el incumplimiento de los deberes matrimoniales. No se vislumbra ninguna buena razón para impedir, a priori, una posible indemnización por el incumplimiento de los deberes matrimoniales" (considerando $8^{\circ}$ ).

${ }^{27}$ Una presentación de los argumentos a favor del resarcimiento de los daños ocasionados en las relaciones familiares y especialmente de los que pudieran derivar de la infracción de deberes conyugales en Hernández (2008), pp. 13s.; Sambrizzi (2001), pp. 139ss.; Rueda (2014), pp. 276s.; Barcia y Rivera (2015), pp. 26s.; Valenzuela (2012), pp. 247-251; TAPIA (2016), p. 163; VARgas (2009), pp. 179-221; Turner (2013), pp. 168s.

${ }^{28}$ Véanse Medina (2008), pp. 79ss.; Vargas (2009), pp. 249ss.; Sáinz-Cantero y PÉrez (2012), pp. 93ss.

${ }^{29}$ VARGas (2009), pp. 235s. 
habida cuenta de que el contractual está diseñado para las convenciones creadoras de derechos regidas por la autonomía privada (y no por la ley), entre las que no está el matrimonio ${ }^{30}$.

Por las razones que expondré, opino contra la indemnización por las inmediatas consecuencias derivadas de la infracción de deberes conyugales, por ejemplo, del de fidelidad o del de cohabitación ${ }^{31}$. Naturalmente, me refiero a las consecuencias directas de dicha infracción (constitutivas de las típicas perturbaciones presentes en estos casos) y no a efectos subsecuentes vinculados con la misma que pudieran constituir un daño anormal y, por tanto, indemnizable. Así, por ejemplo, tratándose del deber de fidelidad, no deberían resarcirse las inmediatas perturbaciones derivadas de su infracción (como la angustia, la decepción o el desamor), pero sí, en su caso, los menoscabos provenientes de una ocultación de paternidad o de la transmisión de una enfermedad venérea ${ }^{32}$.

Según se verá, la anterior es la conclusión que puede extraerse de las sentencias que se han pronunciado en nuestro medio acerca de la indemnización por infracción de deberes conyugales ${ }^{33}$.

${ }^{30}$ Véanse De Verda y Chaparro (2012), p. 118; VArgas (2009), pp. 73-76; SáinZCantero y Pérez (2012), pp. 31-33; Mendoza (2011), pp. 52-54. En nuestro medio las 102 sentencias, en general, no se han pronunciado sobre el punto, con la salvedad, por ejemplo, de la dictada en Pinto con Rojas (2014), en cuyo considerando $13^{\circ}$ se lee lo siguiente: "los sentenciadores están con la posición de aquellos que sostienen que la indemnización de los daños derivados de los hechos causales del divorcio sanción, se rige, por regla general, por el estatuto de la responsabilidad civil extracontractual". Puede consultarse también la sentencia de la Corte de Apelaciones de Santiago de Riddel con Albornoz (2010), en que, ante una demanda de responsabilidad extracontractual de la cónyuge por violencia intrafamiliar y transmisión de una enfermedad venérea, se confirmó la sentencia de primera instancia, que no dio lugar al resarcimiento por tratarse de un supuesto de responsabilidad contractual. La Corte Suprema (2012) desechó los recursos de casación en la forma y en el fondo por incumplimiento de sus presupuestos.

${ }^{31}$ Véanse Ferrer (2001), pp. 15s.; SEverín (2008 a), pp. 134ss.; Roca (2000) passim.

${ }^{32}$ Una presentación de los argumentos contra la responsabilidad civil en sede de familia y especialmente por los daños que pudieran derivar de la infracción de deberes conyugales en Hernández (2008), pp. 11-13; De Verda y Chaparro (2012), pp. 103-118; Fleitas (2001), pp. 177-179; Valenzuela (2012), pp. 245-247; SAmbrizzi (2001), pp. 134137; Barcia y Rivera (2015), pp. 24-26; Mendoza (2011), pp. 42ss.; Rueda (2014), pp. 273-276; Severín (2008 a), pp. 115s.; Vargas (2009), pp. 97ss.; Sáinz-Cantero y Pérez (2012), pp. 12ss.; TAPIA (2016), pp. 163s.

${ }^{33}$ Corral (2014), p. 58. En el derecho comparado, aun cuando no se pueden extraer conclusiones categóricas, la jurisprudencia varía dependiendo del ordenamiento de que se trate. Así, por ejemplo, en España los tribunales han sido reacios a conceder indemnización, mientras que en Francia e Italia han sido proclives. Véanse Novales (s/a), p. 125; De Verda y Chaparro (2012), pp. 111-115. Estos últimos aluden a las sentencias de la Corte de Casación francesa de 11 de enero de 2005, que condenó a resarcimiento a la cónyuge por "comportamiento violento, injurioso y humillante; incluso en presencia de terceros, 
En lo que sigue desarrollo los argumentos que me llevan a descartar que, en general y en particular en el caso del derecho chileno, deban resarcirse las consecuencias inmediatas de la infracción de deberes matrimoniales.

\section{JURIDICIDAD RESTRINGIDA DE LOS DEBERES CONYUGALES}

La improcedencia de la responsabilidad civil ante las consecuencias de la infracción de deberes conyugales implica que, aun cuando gozan de juridicidad, cuentan con una de carácter restringido. Es decir, a pesar de que disfrutan de cierto grado de juridicidad, por estar tipificados y poder dar lugar su infracción al divorcio o la separación judicial, no cuentan con un nivel máximo de juridicidad, limitándose esta a los referidos efectos, sin que las consecuencias de su vulneración deban dar lugar a indemnización.

La afirmación de que los deberes matrimoniales cuentan con una juridicidad restringida -que se traduce en la inaplicabilidad de la responsabilidad civil ante las consecuencias de su infracción- deriva de la circunstancia de que no son obligaciones ${ }^{34}$; de la especificidad de los efectos contemplados por el derecho de familia en caso de incumplirse ${ }^{35}$; de la protección de los derechos fundamentales de los cónyuges; y de las prácticamente insalvables dificultades para dar por concurrentes los presupuestos de la responsabilidad civil ante la materialización de dichas consecuencias (principalmente, el daño, la causalidad y la imputabilidad).

\section{LOS DEBERES CONYUGALES NO SON OBLIGACIONES}

\section{Sintesis}

En primer término, la juridicidad restringida de los deberes conyugales está avalada por la circunstancia de que, técnico-jurídicamente-, no son obligaciones $^{36}$. Esto se debe a que, básicamente y a diferencia de ellas,

respecto de su marido"; y de la Corte de Casación Civil italiana de 10 de mayo de 2005, que condenó al marido a indemnizar a su esposa el daño sexual padecido por no haberle informado de su impotencia antes de casarse.

${ }^{34}$ Argumento desarrollado en VARGas (2009), pp. 124-144.

${ }^{35}$ FERRER (2001), p. 14; Roca (2000), p. 541. Un tratamiento en profundidad de este argumento en VARGAS (2009), pp. 145-175.

${ }^{36} \mathrm{El}$ legislador, para aludir a los deberes conyugales, habla indistintamente de obligaciones y deberes. Utiliza la primera expresión en el Título VI del Libro I del Código Civil, denominado “Obligaciones y Derechos entre los Cónyuges”. Emplea la segunda, en los artículos 5.4, 10, 11, 20 y 
presentan una faceta moral que prima sobre la jurídica; y no admiten cumplimiento compulsivo en naturaleza ${ }^{37}$. De ambos asertos deriva que las consecuencias de su incumplimiento, contrariamente a lo que sucede con el de las obligaciones, no dan lugar a indemnización.

\section{Primacía de la faceta moral en los deberes conyugales}

\section{a) Preliminar}

Los deberes matrimoniales presentan un carácter moral que prima sobre su faceta jurídica ${ }^{38}$. En este sentido, en la sentencia de la Corte de Apelaciones de Santiago pronunciada en Prado Cuevas con Alcalde Ochagavía y otro (2009) se indica que "las relaciones de familia tienen un fuerte componente ético que sobrepasa, con mucho, el ámbito estrictamente jurídico" (considerando $15^{\circ}$ ). No ocurre lo mismo con las obligaciones, que se caracterizan por ser vínculos plenamente jurídicos o por presentar un carácter marcadamente jurídico en desmedro del moral que eventualmente pudieran tener. Esta idea se trasunta en la citada sentencia al expresar que la indemnización solo procede en caso de "obligaciones de carácter patrimonial". El fallo señala lo siguiente: "finalmente, el hecho que el adulterio siempre haya tenido una sanción especial, establecida 104 por el legislador en consideración a la naturaleza de la institución del matrimonio, piedra fundamental del derecho de familia, no permite considerarlo fuente de responsabilidad extracontractual como lo pretende el demandante, pues la normas que regulan tales materias se refieren a la reparación de daños derivados de obligaciones de carácter patrimonial, motivo por el cual no resulta jurídicamente procedente acoger la presente demanda" (considerando $21^{\circ}$-cursivas mías-).

Existen varios argumentos para sostener que en los deberes matrimoniales prima la faceta moral. Son los siguientes: su particular configuración normativa responde a una determinada visión moral del matrimonio y su cumplimiento depende de las convicciones de los cónyuges (como ocurre con los de fidelidad y cohabitación); la circunstancia de que relevantes ordenamientos comparados hayan optado por no positivarlos o derogar

33 de la Ley $\mathrm{N}^{\circ}$ 19.947, de 2004. Naturalmente, lo que le confiere el estatus de obligación a un determinado vínculo, en un sentido técnico-jurídico, no es su denominación legislativa, sino la configuración y producción de los efectos de las obligaciones.

${ }^{37}$ Abeliuk (2014), p. 36; Ferrer (2001), p. 14. Otros argumentos para descartar que los deberes conyugales sean obligaciones en Otárola (2014), p. 189.

${ }^{38}$ Ramos (2005), p. 124; TAPIa (2016), pp. 166s. En contra, Novales (2007), p. 65; Sáinz-Cantero y Pérez (2012), p. 31. Cabe insistir en que la faceta jurídica de los deberes conyugales implica que están tipificados y que su infracción puede dar lugar al divorcio o la separación judicial. 
el divorcio sanción (concebido como respuesta a su infracción) da cuenta de la consideración del legislador de las actuales creencias los ciudadanos; el ordenamiento no sanciona con el divorcio o la separación judicial toda infracción a ellos, sino solo las relevantes; y el legislador no exige aludir a ellos en los acuerdos sobre separación.

b) particular configuración normativa de los deberes conyugales: fidelidad y cohabitación

Por lo que atañe al deber de fidelidad, la evolución del tratamiento del adulterio -que es la conducta que más claramente lo infringe- da cuenta de su eminente carácter moral ${ }^{39}$, ya que la creencia de que debía regularse como un delito penal y que lo podían cometer las mujeres exclusivamente, es desplazada por la que asume que solo tiene cierta relevancia civil y que lo pueden cometer hombres y mujeres en los mismos términos ${ }^{40}$. A mayor abundamiento, el artículo 33 de la Ley $\mathrm{N}^{\mathrm{o}} 19.947$, de 2004, establece que el deber de fidelidad se suspende en caso de separación judicial ${ }^{41}$ y, el 26 (2), que -al efecto de solicitarla- "(n)o podrá invocarse el adulterio cuando exista previa separación de hecho consentida por ambos cónyuges”. La suspensión del mencionado deber, a pesar de permanecer vigente el matrimonio, se debe a que el legislador, teniendo en cuenta la forma en que -de acuerdo a sus creenciasse comportan las personas en situación de crisis matrimonial, no consideró razonable mantener su exigibilidad. Así, el ordenamiento concibe la infracción del deber de fidelidad exclusivamente como una causa de separación judicial o divorcio, es decir, se pronuncia sobre él solo por la necesidad de regular los efectos de la ruptura de la vida matrimonial, no asignándole a su incumplimiento (pudiendo hacerlo) más consecuencias que aquellas, de lo que se colige que su juridicidad se encuentra limitada a dichos efectos. Esto da cuenta de que en el referido deber (como en todos los matrimoniales) prima la faceta moral sobre la jurídica. Además, cabe tener en cuenta que existen cónyuges que, voluntariamente, conforme a sus convicciones, han decidido no mantener relaciones sexuales únicamente entre ellos $^{42}$.

${ }^{39}$ Cfr. Gil, Fama y Herrera (2006), pp. 255ss.

${ }^{40}$ Tanto en este punto como en otros, el proceder histórico del legislador chileno ha respondido a una forma determinada de concebir las relaciones entre derecho de familia y sexualidad. Casas y Hernández (2009), pp. 35-71. En Argentina, el Código Civil y Comercial de la Nación habla derechamente de "deber moral de fidelidad" (artículo 431).

41 "La separación judicial deja subsistentes todos los derechos y obligaciones personales que existen entre los cónyuges, con excepción de aquellos cuyo ejercicio sea incompatible con la vida separada de ambos, tales como los deberes de cohabitación y de fidelidad, que se suspenden".

${ }^{42}$ En este sentido, se ha postulado que un pacto de exclusión de deberes conyugales, por ejemplo, del de fidelidad, podría constituir una causal de justificación que, en cuanto tal, deseche la responsabilidad. Sáinz-Cantero y Pérez (2012), pp. 83s. 
Considerando lo anterior, es perfectamente posible que los cambios en las concepciones morales de la sociedad redunden en que en el porvenir el adulterio pierda su actual importancia civil, como ha acontecido en otros ordenamientos, que ya no establecen el deber de fidelidad o en que el divorcio por causales (una de las cuales es el adulterio) ha disminuido significativamente o desaparecido. En este sentido, la Ley $\mathrm{N}^{\mathrm{o}} 20.830$, de 2015 , no contempló el deber de fidelidad entre los convivientes, lo que representa un reforzamiento de su pérdida de relevancia, derivada de la clara transformación de las creencias ciudadanas en este terreno.

Por lo que concierne al deber de cohabitación, también la evolución de su tratamiento da cuenta de su eminente carácter moral al transitar desde su aplicación prácticamente solo a la mujer (en el contexto de la "potestad marital”) hasta resultar exigible a ambos cónyuges igualitariamente. Además y como es lógico, el artículo 33 de la Ley $\mathrm{N}^{\circ}$ 19.947, de 2004, dispensa a los consortes de cumplirlo en caso de separación judicial. Su suspensión, pese a permanecer en pie el matrimonio, se debe a que el legislador, teniendo en cuenta la forma en que se conducen los individuos en situación de crisis matrimonial, no consideró razonable mantener su exigibilidad. Asimismo, existen matrimonios que, voluntariamente, conforme a sus convicciones o necesidades, han decidido no vivir en el mismo hogar ${ }^{43}$.

c) Derogación de los deberes conyugales y del divorcio sanción en otros ordenamientos

También fundamenta la idea de que en los deberes conyugales sobresale la arista moral en desmedro de la jurídica la circunstancia de que en relevantes ordenamientos comparados han dejado de estar positivados ${ }^{44}$ o se ha procedido a derogar el divorcio por causales, una de las cuales era la infracción de dichos deberes. Así, es cada vez más frecuente que el divorcio por causales ceda terreno al divorcio abstracto, desconectado de la exigencia de hipótesis específicas para su procedencia. Es lo que ha ocurrido, destacadamente, en el derecho español, en que los cónyuges pueden optar por divorciarse al margen de si alguno se ha comportado de manera distinta a lo esperable en la vida matrimonial ${ }^{45}$.

La referida tendencia da cuenta de que las aludidas legislaciones, respondiendo a la forma en que se comportan los individuos, sobre todo ante una crisis matrimonial, han optado por restar importancia a los

${ }^{43}$ Véase la nota anterior y Gil, FAma y Herrera (2006), pp. 252s.

${ }^{44}$ Gil, Fama y Herrera (2006), p. 251.

${ }^{45}$ Las causales legales de separación y divorcio fueron suprimidas en España por la Ley $15 / 2005$, de 8 de julio, manteniéndose, sin embargo, los deberes conyugales. Novales (2007), p. 65; Sáinz-Cantero y Pérez (2012), pp. 29s. 
deberes conyugales. Este tipo de opción es congruente con el papel del derecho de familia contemporáneo, que no está llamado a hacerse cargo de conflictos que presentan una carga moral preeminente, sino a solucionar controversias jurídicamente trascendentes, de manera mínimamente invasiva de la intimidad y autonomía privada y sin provocar un desgaste injustificado del aparato jurisdiccional; lo que implica que no tiene por misión dar respuesta a todos los entredichos que tengan lugar en la vida familiar o marital.

d) No siempre procede el divorcio o la separación judicial por infracción de deberes conyugales

Otro argumento que avala la idea de que en los deberes conyugales prima la faceta moral es que -conforme a los artículos 26 (1) y 54 (1) y n 2 de la Ley $\mathrm{N}^{\mathrm{o}} 19.947$, de 2004- el divorcio y la separación judicial solo proceden ante infracciones graves que tornen intolerable la vida en común y, en caso de incumplimiento de los deberes de convivencia, socorro o fidelidad, el primero procede solo ante vulneraciones graves y reiteradas. De esta forma, ni siquiera las consecuencias propias de la vulneración de dichos deberes (divorcio y separación judicial) proceden en todo caso, sino solo en supuestos calificados. Esta solución revela que el ordenamiento, considerando las costumbres de los individuos, ha optado por tolerar infracciones a los mencionados deberes que, jurídicamente, no estima relevantes; siendo la prueba más palmaria de que entiende que el cumplimiento de los deberes matrimoniales queda entregado a la voluntad o moral de los cónyuges ${ }^{46}$.

e) Deberes conyugales y acuerdos en caso de separación

También avala la idea de que en los deberes matrimoniales prima la faceta moral, la circunstancia de que tampoco se exige que los cónyuges se refieran a ellos en los acuerdos que suscriban en caso de separación (de

${ }^{46}$ El artículo 26 (1) de la Ley No 19.947, de 2004, establece lo siguiente: “(1)a separación judicial podrá ser demandada por uno de los cónyuges si mediare falta imputable al otro, siempre que constituya una violación grave de los deberes y obligaciones que les impone el matrimonio, o de los deberes y obligaciones para con los hijos, que torne intolerable la vida en común”; el 54 (1), que “(e)l divorcio podrá ser demandado por uno de los cónyuges, por falta imputable al otro, siempre que constituya una violación grave de los deberes y obligaciones que les impone el matrimonio, o de los deberes y obligaciones para con los hijos, que torne intolerable la vida en común"; y el $54 \mathrm{n}^{\circ} 2$, que una de las causales específicas para solicitar el divorcio es la "(t)rasgresión grave y reiterada de los deberes de convivencia, socorro y fidelidad propios del matrimonio". Asimismo, las hipótesis de infracción de deberes conyugales que pueden configurar causales de indignidad para suceder o de desheredamiento son especialmente graves (véanse los artículos 968 y ss. y 1207 y ss. respectivamente, del Código Civil). 
hecho o judicial). Los artículos 21 y 27 (2) -que se remite al anterior- de la Ley $\mathrm{N}^{\circ}$ 19.947, de 2004, solo aluden al derecho de alimentos, el régimen de bienes y las relaciones con los hijos, sin que lo hagan a los deberes conyugales. La circunstancia de que el legislador no exija referirse a ellos revela que no les otorga mayor relevancia jurídica, considerándolos como vinculaciones de carácter preferentemente moral ${ }^{47}$.

\section{Los deberes conyugales no admiten cumplimiento compulsivo y, subsiguientemente, su infracción no da lugar a indemnización}

Un segundo argumento justificante de la tesis de que los deberes conyugales no son obligaciones, aparte de la primacía de su faceta moral, es la circunstancia de que no admiten cumplimiento compulsivo en naturale$\mathrm{za}^{48}$. De esto deriva que su infracción no dé lugar a indemnización al ser esta un cumplimiento por equivalencia que, en cuanto tal, reemplaza la conducta objeto de la obligación ${ }^{49}$.

${ }^{47}$ El artículo 21 de la Ley $\mathrm{N}^{\circ}$ 19.947, de 2004, prescribe que “(s)i los cónyuges se separaren de hecho, podrán, de común acuerdo, regular sus relaciones mutuas, especialmente los alimentos que se deban y las materias vinculadas al régimen de bienes 108 del matrimonio./ En todo caso, si hubiere hijos, dicho acuerdo deberá regular también, a lo menos, el régimen aplicable a los alimentos, al cuidado personal y a la relación directa y regular que mantendrá con los hijos aquel de los padres que no los tuviere bajo su cuidado. En este mismo acuerdo, los padres podrán convenir un régimen de cuidado personal compartido./ Los acuerdos antes mencionados deberán respetar los derechos conferidos por las leyes que tengan el carácter de irrenunciables”. El artículo 27 (2), respecto de la solicitud de separación judicial, establece que "(s)i la solicitud fuere conjunta, los cónyuges deberán acompañar un acuerdo que regule en forma completa y suficiente sus relaciones mutuas y con respecto a sus hijos. El acuerdo será completo si regula todas y cada una de las materias indicadas en el artículo 21. Se entenderá que es suficiente si resguarda el interés superior de los hijos, procura aminorar el menoscabo económico que pudo causar la ruptura y establece relaciones equitativas, hacia el futuro, entre los cónyuges cuya separación se solicita”.

${ }^{48}$ Severín (2008 a), p. 124; Barcia y Rivera (2015), pp. 22s.; Martín-Casals y Ribot (2011), p. 545; Ramos (2005), p. 124; Novales (2007), pp. 83ss. Cabe precisar, en relación con el deber de socorro, que sí procede la exigibilidad en naturaleza de forma compulsiva del derecho de alimentos, lo cual se debe a que se encuentra configurado como un verdadero derecho (que incluso cuenta con normas específicas de cumplimiento forzado), desencadenante de la correlativa obligación alimentaria, situándose el derecho de alimentos, por tanto, más allá del puro deber de socorro que, en rigor, queda circunscrito al despliegue de conductas de ayuda distintas de la representada por el cumplimiento de aquél. RAmos (2005), p. 127.

${ }^{49}$ FERRER (2001), p. 14. Cabe recordar que la noción de obligación alude a dos esferas: la relación de débito y la de responsabilidad(ABELIUK -2014-, pp. 47-49), siendo esta última la que aquí importa. El elemento responsabilidad "señala la posibilidad que tiene el acreedor, una vez establecida la renuencia del obligado al pago, de exigir coercitivamente la prestación específica determinada en el título y, en subsidio, trocado el bien o servicio en dinero, realizar la expropiación forzosa de los bienes del deudor por causa de utilidad privada, 
Los deberes conyugales son figuras a cuya infracción el legislador conecta determinadas consecuencias (separación judicial o divorcio) para los casos de mayor entidad, pero no están referidos a comportamientos jurídicamente exigibles, ni de forma compulsiva ni por equivalencia. Este proceder se debe solo a que el ordenamiento ha optado por dar una solución específica (separación judicial o divorcio) a las crisis matrimoniales generadas por dicha infracción (grave y reiterada); pero no a que ha otorgado el estatus de obligaciones (jurídicamente exigibles) a los referidos deberes.

Que la indemnización sea un sustituto de la conducta objeto de la obligación implica que esta podría haber sido exigida en algún instante en naturaleza, lo que no acontece con el comportamiento a que se refieren los deberes conyugales, que no es exigible en naturaleza en ningún momento. La diferencia con las obligaciones estriba en que estas son exigibles en naturaleza desde su nacimiento o desde que se verifica la modalidad a que están supeditadas, reemplazándose, en general, la conducta constitutiva de su objeto por la indemnización cuando no es posible su cumplimiento en naturaleza. Mientras que en el caso de las obligaciones la imposibilidad de exigir el cumplimiento en naturaleza -que justifica el reemplazo por la indemnización- es sobreviniente, en el de los deberes conyugales se presenta desde el comienzo del matrimonio ${ }^{50}$.

hasta concurrencia del equivalente pecuniario de la prestación y de los perjuicios del incumplimiento, mediante proceso ejecutivo". Hinestrosa (2002), p. 78. Así, un primer momento de la relación de responsabilidad es el de ejecución forzada de la obligación, mientras que un segundo instante es el de la subasta de los bienes del deudor hasta el monto del valor de la prestación y los perjuicios derivados del incumplimiento. La consideración de los deberes conyugales como obligaciones, en un sentido técnico-jurídico pleno, choca con dos obstáculos. El primero consiste en que la procedencia de indemnización opera en subsidio de la posibilidad de cumplimiento compulsivo, lo que implica que, si este nunca ha sido posible, tampoco lo será aquella. El segundo consiste en que la subasta de los bienes del deudor, en su caso, ha de referirse no solo a los perjuicios derivados del incumplimiento, sino, además, al valor pecuniario de la prestación, valor que, en relación con los deberes conyugales, nunca será posible determinar. En este sentido, el citado autor ha señalado (p. 81), en referencia a la obligación, que "el nexo entre los sujetos (...) se refiere a una prestación del deudor apreciable en dinero: entrega de cosas, prestación de un servicio fungible o personal”. Además, la referida consideración en relación con los deberes conyugales contrasta con el hecho de que la noción de obligación supone una prestación exactamente determinada en cuanto a su contenido y circunstancias, esto es, en cuanto a su forma, lugar y tiempo de cumplimiento, exactitud que difícilmente puede predicarse de las (amplias e imprecisas) conductas que imponen los deberes conyugales. Por último, las obligaciones suponen la posibilidad de ser modificadas o extinguidas en base a un amplio abanico de posibilidades, lo cual resulta inaplicable a los deberes conyugales al estar proscritos los actos o pactos referidos a ellos (por ejemplo, renuncia y novación).

${ }^{50} \mathrm{Si}$ bien esta idea podría rebatirse argumentando que el hecho de que no quepa la exigibilidad compulsiva de los deberes conyugales es precisamente la justificación de que proceda su cumplimiento por equivalencia, como ocurre en los casos de las obligaciones 
Conforme a lo expuesto, es perfectamente posible que un ordenamiento asuma que determinados individuos son sujetos pasivos en relación con ciertos comportamientos, pero considere que el no apego a ellos no debe traer aparejados los efectos propios o centrales del incumplimiento de las obligaciones, es decir, el cumplimiento forzoso y, en su caso, el por equivalencia. Esto -aparte de acontecer con los deberes conyugales- ocurre con otras figuras que, incluso a pesar de ser llamadas 'obligaciones', como las naturales, no permiten exigir su cumplimiento y, por tanto, tampoco, en su caso, responsabilidad civil ${ }^{51}$. En efecto, si bien el legislador las ha diseñado como "obligaciones" (aun cuando "imperfectas", lo que importa que no son obligaciones per se), es decir, como comportamientos prestacionales que vinculan a determinados sujetos (acreedor y deudor), no asocia a su vulneración la posibilidad de cumplimiento forzado y tampoco, consecuencialmente, por equivalencia, sino solo la de que el acreedor retenga el pago voluntariamente efectuado por el deudor ${ }^{52}$. Lo mismo acaece con otras figuras jurídicas en relación con las cuales el legislador procede en similares términos, como ocurre (para mencionar una del derecho de familia) con la promesa de matrimonio mutuamente aceptada, cuyo cumplimiento compulsivo tampoco es exigible, sin que lo sea asimismo una indemnización por su quebrantamiento, ni siquiera

cuyo cumplimiento en naturaleza ya no es posible (de hacer y, discutiblemente, de dar); en estos últimos supuestos la imposibilidad de cumplimiento forzado generadora de la subrogación indemnizatoria es posterior al nacimiento de la obligación, contrariamente a lo que ocurre en el de los deberes conyugales, en que la imposibilidad se presenta desde que nacen, es decir, a partir de la celebración del matrimonio.

${ }^{51}$ Este parangón no implica igualar estas obligaciones y los deberes conyugales, ya que respecto de aquellas pueden tener lugar actos inaplicables a estos (constitución de cauciones y novación, por ejemplo). Es lo que acontece con la generalidad de los deberes morales. Moisset de EsPanés (2013), p. 69.

${ }^{52}$ Precisamente, el hecho de que las obligaciones naturales sean imperfectas las priva de su calidad de obligaciones en términos técnico-jurídicos plenos, acercándose más su estatus al de los deberes morales, tal y como sucede con los deberes conyugales. Esto, al igual que en el caso de dichos deberes, no significa que las obligaciones naturales carezcan de juridicidad (representada por el otorgamiento de una excepción al acreedor y por la prescripción legal de determinados efectos). En esta línea, HinEsTrosa (2002), p. 94 ha sostenido que "el hecho es que el código expresa la razón de la diferencia entre las obligaciones propiamente dichas y las llamadas "obligaciones naturales": la obligación es coercible, se puede alegar por vía de acción y de excepción, en tanto que esos otros deberes simplemente autorizan la retención de lo dado por quien quiso satisfacerlos". Agrega -pp. 98s.- que “(...) la obligación natural es o, mejor, corresponde a un deber moral, del que hay lugar a ocuparse solamente en términos retrospectivos: por la necesidad o conveniencia de justificar una atribución patrimonial que no se apoya en una solvendi causa ordinaria, pero que tampoco se muestra basada en una credendi causa y, menos todavía, en una donandi causa" (subrayado en cursivas en el original). 
a pesar de haberse pactado expresamente, sin perjuicio del derecho de retener la multa acordada cuando haya sido pagada ${ }^{53}$.

En síntesis, el comportamiento objeto de los deberes conyugales solo representa una conducta que idealmente debe llevarse a cabo al interior de la vida matrimonial. Por esto es que su inobservancia (grave y reiterada) puede acarrear el quiebre jurídico de aquella (vía separación o divorcio), mas no su exigibilidad judicial al cónyuge infractor ni tampoco la necesidad de que este efectúe una prestación de reemplazo ${ }^{54}$.

\section{ESPECIFICIDAD DE LAS SANCIONES DEL DERECHO DE FAMILIA}

\section{El ordenamiento jurídico contempla como efectos ante la infracción de los deberes conyugales el divorcio y la separación judicial, pero no la indemnización}

Otro argumento para descartar la indemnización por las consecuencias de la infracción de deberes conyugales es que el derecho de familia prescribe efectos específicos ante aquella, como el divorcio y la separación judicial, sin que haya contemplado, pudiendo hacerlo, la responsabilidad civil ${ }^{55}$.

${ }^{53}$ En relación con esta cuestión, véanse CARRIÓN (2006), pp. 117ss.; SÁINZ-CANTERO y Pérez (2012), pp. 76-78.

${ }^{54}$ Incluso sosteniéndose que tales deberes son técnicamente obligaciones, ha de arribarse a idéntica conclusión, ya que, siéndolo, pertenecerían al grupo de aquellos vínculos jurídicos no susceptibles de exigirse compulsivamente y, consecuencialmente, por equivalencia, como ocurre con las obligaciones naturales y la promesa de matrimonio mutuamente aceptada, quedando el cumplimiento de aquellos, por ende, al igual que en el caso de estas dos figuras, entregado a la voluntad de las partes.

${ }^{55}$ Esta idea se resume entre los autores bajo la fórmula de especialidad del derecho de familia. Véanse López de la Cruz (2010), p. 16; Ferrer (2001), p. 14; Roca (2000), p. 547. Una de las sentencias que en nuestro medio recoge dicha fórmula es la pronunciada por la Corte de Apelaciones de Puerto Montt en Niklitsckeck con Rosas (2010), en que se lee lo siguiente: "Décimosegundo: Que, entonces, nos encontramos que la causa de los cheques, sería una indemnización de daño moral, por incumplimiento de una obligación contractual, la de guardarse fe en el matrimonio./ Décimotercero: Que como la mayoría de la jurisprudencia y doctrina lo ha sostenido, en nuestro ordenamiento jurídico el daño moral en materia de incumplimiento contractual no es indemnizable, pues no existe en el Título XII del Libro Cuarto del Código Civil, una disposición como la del artículo 2329 del mismo Código para el caso de la responsabilidad extracontractual, de manera que debemos estarnos al artículo 1556 que limita la responsabilidad al daño emergente y lucro cesante (...)”. Por su parte, la sentencia de la Corte de Apelaciones de Santiago, dictada en Prado Cuevas con Alcalde Ochagavía y otro (2009), señala que "los diferentes ordenamientos jurídicos han tratado de mantener los conflictos matrimoniales dentro de cierto grado de discreción, por lo cual, los legisladores, anticipándose al conflicto, han precisado las consecuencias de la infracción, como en el caso de autos, al deber de fidelidad. 
Si bien este argumento, por sí solo, no elimina la posibilidad de aplicar las reglas de la responsabilidad civil (que, en general, operan a pesar de que el legislador no haya dicho nada respecto de un ámbito particular), sumada a las consideraciones desarrolladas y por desarrollar, sí resulta determinante.

\section{El ordenamiento jurídico contempla expresamente efectos patrimoniales en materia de derecho de familia e incluso la responsabilidad civil, pero no ante las consecuencias de la infracción de deberes conyugales}

La idea expresada en el precedente párrafo se refuerza porque, en materia de derecho de familia nuestro ordenamiento contempla efectos patrimoniales en determinados casos, por ejemplo, el derecho de alimentos, los asociados al régimen económico del matrimonio, el bien familiar y la compensación económica; sin que lo haga ante las consecuencias de la infracción de deberes conyugales.

A la referidas prescripciones cabe agregar que los artículos 21 y 27 (2) -que se remite al anterior- de la Ley $\mathrm{N}^{\mathrm{O}} 19.947$, de 2004, no mencionan explícitamente entre las materias a cuyo respecto puede extenderse el correspondiente acuerdo en caso de separación de hecho o judicial

112 a los deberes matrimoniales, aludiendo expresamente, en cuanto a las relaciones entre cónyuges, exclusivamente al derecho de alimentos y al régimen de bienes.

Incluso, el ordenamiento jurídico contempla expresamente, en materia de derecho de familia, la responsabilidad civil ante determinadas conductas dañosas $^{56}$. Es lo que acontece, a la luz del Código Civil, en materia de acciones de filiación, bien familiar, administración de los bienes del hijo, derecho de alimentos, sociedad conyugal y participación en los gananciales $^{57}$. Sin embargo, no hay norma que contemple expresamen-

Es decir, el derecho de familia por su especialidad, contempla sus propias sanciones, no siendo aplicable en consecuencia, las normas generales sobre responsabilidad civil y por ende no corresponde -en un caso como el de autos- solicitar ni mucho menos conceder la reparación del daño moral" (considerando $19^{\circ}$ ). En esta misma línea cabe tener en cuenta la sentencia de la Corte de Apelaciones de Talca, pronunciada en Abarca con González (2012).

${ }^{56}$ LEPín (2014), pp. 408-411. Constata similar proceder en el derecho español RocA (2000), pp. 543ss.

${ }^{57}$ Se refieren a cada uno de estos casos, respectivamente, los siguientes artículos del Código Civil: 197 (2), que establece que "(1)a persona que ejerza una acción de filiación de mala fe o con el propósito de lesionar la honra de la persona demandada es obligada a indemnizar los perjuicios que cause al afectado"; 141 (final), que prescribe que "(e) 1 cónyuge que actuare fraudulentamente para obtener la declaración a que refiere este artículo, deberá indemnizar los perjuicios causados, sin perjuicio de la sanción penal que 
te la indemnización ante las consecuencias de la infracción de deberes conyugales ${ }^{58}$.

\section{Cuando el ordenamiento jurídico vinculó consecuencias patrimoniales a los deberes conyugales o a su infracción, lo hizo expresamente}

\section{Adicionalmente y al margen de las anteriores consideraciones globales, cabe tener en cuenta que cuando el ordenamiento jurídico decidió vincular}

pudiere corresponder"; 256, que señala que “(e)1 padre o madre es responsable, en la administración de los bienes del hijo, hasta de la culpa leve./ La responsabilidad para con el hijo se extiende a la propiedad y a los frutos, en aquellos bienes del hijo en que tiene la administración, pero no el goce, y se limita a la propiedad cuando ejerce ambas facultades sobre los bienes"; 328, que dispone que “(e)n el caso de dolo para obtener alimentos, serán obligados solidariamente a la restitución y a la indemnización de perjuicios todos los que han participado en el dolo"; 1748 (1), 1768 , 1771, que establecen, respectivamente, que “(c)ada cónyuge deberá asimismo recompensa a la sociedad por los perjuicios que le hubiere causado con dolo o culpa grave, y por el pago que ella hiciere de las multas y reparaciones pecuniarias a que fuere condenado por algún delito o cuasidelito"; que "(a) quel de los cónyuges o sus herederos que dolosamente hubiere ocultado o distraído alguna cosa de la sociedad, perderá su porción en la misma cosa y se verá obligado a restituirla doblada"; y que "(1)as pérdidas o deterioros ocurridos en dichas especies o cuerpos ciertos deberá sufrirlos el dueño, salvo que se deban a dolo o culpa grave del otro cónyuge, en cuyo caso deberá éste resarcirlos"; y 1792-18, conforme al que "(s)i alguno de los cónyuges, a fin de disminuir los gananciales, oculta o distrae bienes o simula obligaciones, se sumará a su patrimonio final el doble del valor de aquéllos o de éstas". Respecto de los daños entre cónyuges relacionados con el régimen de bienes del matrimonio, véase Roca (2000), pp. 543ss.

${ }^{58}$ De considerarse indemnización la compensación económica, podría concluirse que el legislador quiso que procediera solo ante menoscabos tipificados (los del artículo 61 de la Ley $\mathrm{N}^{\circ} 19.947$, de 2004) y no ante cualquier detrimento, o sea, no ante las consecuencias de la infracción de deberes conyugales; con el agregado de que puede proceder incluso en favor del cónyuge que provocó la crisis de que se trata por haber vulnerado un deber matrimonial. En este sentido, RocA (2000), pp. 547ss. -respecto del derecho español-. Un análisis de la eventual compatibilidad de la compensación económica y la indemnización entre cónyuges en el derecho chileno en SEverín (2008 a) pp. 101ss., quien se inclina por considerar que, atendido el objeto y naturaleza de la primera, no existe inconveniente para que, aplicándose, proceda igualmente resarcimiento entre consortes. En nuestro medio, la sentencia pronunciada por la Corte de Apelaciones de Santiago en Cerón con Quezada (2010) estableció la clara diferencia entre la compensación económica y la indemnización en este sentido, no dando lugar a la segunda para resarcir los detrimentos causados por los malos tratos del marido a la cónyuge. Su considerando $5^{\circ}$ apunta que "no es la compensación económica una institución creada para reparar este tipo de perjuicio y puede la actora, si así lo estima, perseguir la responsabilidad del demandado de acuerdo a las normas generales del Código Civil, en la sede y de acuerdo al procedimiento correspondientes, pero lo que no puede pretender es que el supuesto perjuicio que le habrían irrogado los malos tratos del demandado le sean indemnizados por la vía del artículo 61 de la Ley de Matrimonio Civil”. 
consecuencias patrimoniales a los deberes conyugales o a su infracción, lo hizo expresamente, incluso imponiendo en su caso la obligación de indemnizar. Es lo que ocurre, en general, con el derecho a compensación económica en caso de divorcio o nulidad matrimonial ${ }^{59}$; con el deber de socorro, una de cuyas facetas es la obligación/derecho de alimentos ${ }^{60} ; \mathrm{y}$ con el deber de respeto, al contemplar el artículo 11 de la Ley $\mathrm{N}^{\mathrm{O}} 20.066$, de 2005 , la indemnización ante su infracción ${ }^{61}$. Así, el legislador no estableció una norma indemnizatoria amplia a propósito de la infracción de deberes conyugales, sino solo preceptos patrimoniales o resarcitorios específicos, de lo que se colige que no optó en general por la indemnización ante las consecuencias de dicha infracción ${ }^{62}$.

Vinculado con lo anterior y de modo particular, en el caso del deber de fidelidad, el artículo 132 (1) del Código Civil solo prescribe que el adulterio da lugar a las sanciones previstas por la ley, es decir, al divorcio o

${ }^{59} \mathrm{El}$ artículo 61 de la Ley No 19.947 , de 2004, establece lo siguiente: “(s)i, como consecuencia de haberse dedicado al cuidado de los hijos o a las labores propias del hogar común, uno de los cónyuges no pudo desarrollar una actividad remunerada o lucrativa durante el matrimonio, o lo hizo en menor medida de lo que podía y quería, tendrá derecho a que, cuando se produzca el divorcio o se declare la nulidad del matrimonio, se le compense el menoscabo económico sufrido por esta causa”. Respecto de la compensación 114 económica en nuestro ordenamiento puede consultarse ACUÑa (2011), pp. 283ss.

${ }^{60}$ El legislador configuró al derecho de alimentos como la cara jurídicamente exigible (en naturaleza y por equivalencia) del deber de socorro. Así, para otorgarle exigibilidad a un deber matrimonial el ordenamiento se vio en la necesidad de configurar un derecho (el de alimentos) en toda regla.

${ }^{61} \mathrm{El}$ precepto establece lo siguiente: "Desembolsos y perjuicios patrimoniales. La sentencia establecerá la obligación del condenado de pagar a la víctima los desembolsos y perjuicios de carácter patrimonial que se hubieren ocasionado con la ejecución del o los actos constitutivos de violencia intrafamiliar objeto del juicio, incluida la reposición en dinero o en especie de bienes dañados, destruidos o perdidos. Estos perjuicios serán determinados prudencialmente por el juez". Los actos de violencia intrafamiliar están definidos en el artículo 5 como aquéllos "maltratos que afecten la vida o la integridad física o psíquica" de determinados individuos, de manera que no todo acto de infracción a tal deber da lugar a resarcimiento. Acerca de la responsabilidad civil por violencia intrafamiliar véanse ZAIKOSKI (2015), principalmente las pp. 145ss.; BonILla (2012), pp. 178 ss. Otras consecuencias que pueden aplicarse ante una infracción de deberes conyugales son las indignidades para suceder y el desheredamiento (artículos 968 y ss. y 1207 y ss. del Código Civil, respectivamente). Respecto de las primeras, véase SomarRIVA (2008), pp. 127ss.; y, del segundo, Domínguez y Domínguez (2011), pp. 1080ss.

${ }^{62}$ En este sentido, la sentencia de la Corte de Apelaciones de Puerto Montt pronunciada en Niklitsckeck con Rosas (2010), señala lo siguiente: "Es más, cuando el legislador ha querido que por incumplimiento de las obligaciones que surgen como consecuencia del matrimonio uno de los cónyuges deba indemnizaciones al otro lo ha dicho expresamente como en el caso del inciso final del artículo 142 o artículo 328 del Código Civil" (considerando $14^{\circ}$ ). El recurso de casación en el fondo interpuesto contra la sentencia fue rechazado por la Corte Suprema (2012). 
la separación judicial, sin que de lugar, por tanto, a la responsabilidad civil, al no estar prevista expresamente por la ley ${ }^{63}$.

${ }^{63}$ La alusión a las sanciones previstas por la ley que hace el precepto no puede sino referirse a "sanciones específicas", porque no habría tenido sentido que con ella estuviera reiterando la sanción general de indemnización prevista para todo ilícito civil. Diversas sentencias de nuestros tribunales se han pronunciado en este sentido. Así, la de la Corte Suprema en Prado Cuevas y Alcalde Ochagavía y otro (2012), caso referido a una acción de indemnización por infidelidad y ocultación de paternidad solicitada por el actor contra la cónyuge y su amante. Las sentencias de instancia desecharon la demanda señalando que el adulterio es una grave infracción contra el deber de fidelidad pero no un delito civil, básicamente por la especialidad del derecho de familia y porque las normas de la responsabilidad civil operan ante la infracción de obligaciones patrimoniales. La Corte Suprema desechó la casación en el fondo por no cumplirse sus requisitos, aludiendo a que no hubo prueba de los daños y a que no hay responsabilidad civil en este ámbito, remitiéndose a lo señalado por los tribunales de instancia. En este caso, en la sentencia de segunda instancia, pronunciada por la Corte de Apelaciones de Santiago (2009), se señala lo siguiente: "Décimo noveno: Que, en consecuencia, teniendo presente el cúmulo de disposiciones que sancionaban y sancionan el adulterio, es posible concluir que el adulterio, desde siempre, ha sido calificado por el legislador como infracción grave al deber de fidelidad de los cónyuges y no como delito o cuasidelito civil. En efecto, los diferentes ordenamientos jurídicos han tratado de mantener los conflictos matrimoniales dentro de cierto grado de discreción, por lo cual, los legisladores, anticipándose al conflicto, han precisado las consecuencias de la infracción, como en el caso de autos, al deber de fidelidad. Es decir, el derecho de familia por su especialidad, contempla sus propias sanciones, no siendo aplicable en consecuencia, las normas generales sobre responsabilidad civil y por ende no corresponde -en un caso como el de autos- solicitar ni mucho menos conceder la reparación del daño moral". Por su parte, en la sentencia de la Corte de Apelaciones de Puerto Montt pronunciada en Niklitsckeck con Rosas (2010), se señala lo siguiente: "Décimo cuarto: (...) pretender una indemnización por daño moral por una presunta relación extramatrimonial de uno de los cónyuges, es contraria al orden público, ya que aún en el caso de ser comprobada estaríamos frente a lo que el artículo 132 del Código Civil considera una grave infracción al deber de fidelidad que impone el matrimonio lo que según el mismo artículo da origen a las sanciones que la ley prevé, entre las cuales por cierto, las normas de orden público que regulan el matrimonio, no ha considerado la indemnización por daños morales al otro cónyuge. Es más, cuando el legislador ha querido que por incumplimiento de las obligaciones que surgen como consecuencia del matrimonio uno de los cónyuges deba indemnizaciones al otro lo ha dicho expresamente como en el caso del inciso final del artículo 142 o artículo 328 del Código Civil". El recurso de casación en el fondo deducido contra la sentencia fue rechazado por la Corte Suprema (2012). Por su parte, en la sentencia de la Corte de Apelaciones de Rancagua pronunciada en F. M., H. con V. C., M (2007), se lee: “cabe señalar que este rubro no lo contempla la Ley 19.947, razón suficiente para que sea rechazado su pago, tanto más si en la especie no se dio ni se dará lugar al divorcio por la causal culposa invocada por aquella. La extrapolación que pretende la apelante del pago del daño moral en los términos que señala el art. 2329 del Código Civil al ámbito de familia, no resulta pertinente, puesto que, situado dicho pago solo en el ámbito extracontractual, recientemente se ha extendido a la responsabilidad contractual, integración que aún no alcanza a aquellas situaciones que por el cese de la vida en común puedan afectar seriamente a uno o a ambos cónyuges recíprocamente, y que impliquen aquellos sufrimientos a que se refiere el apelante”. 


\section{Corolario}

Considerando que las normas pertinentes dan cuenta de una marcada opción por regular específicamente los efectos patrimoniales de las figuras relevantes del derecho de familia, no es razonable concluir que, aun cuando el legislador no haya prescrito una consecuencia de aquel tipo para la infracción de deberes conyugales, igualmente esta deba dar lugar a una, por ejemplo, la indemnización.

Cabe agregar que la Ley $\mathrm{N}^{\mathrm{O}} 19.947$, de 2004, tuvo la posibilidad de regular la cuestión resarcitoria al estar presente en el debate jurídico comparado desde antes de su entrada en vigencia; y que para su dictación se tuvieron a la vista ordenamientos extranjeros que contemplan explícitamente la procedencia de indemnización ante el divorcio, como el francés ${ }^{64}$. Si el legislador chileno, pudiendo hacerlo, no contempló efectos patrimoniales específicos (indemnización, por ejemplo) para la violación de deberes conyugales, no obstante haberlo hecho en otras situaciones y ordenamientos en los que se inspiró, es porque entendió que las consecuencias de aquella no deben generar efectos diversos de los expresamente prescritos ${ }^{65}$.

${ }^{64}$ Algunos códigos civiles establecen la indemnización entre cónyuges por los hechos vinculados con el divorcio o la separación. Así, el artículo 266 del Código Civil francés establece, respecto del divorcio y la separación, la obligación de indemnizar las consecuencias de especial gravedad producidas por la ruptura matrimonial reprochable a uno de los consortes. El precepto señala que "(s)ans préjudice de l'application de l'article 270, des dommages et intérêts peuvent être accordés à un époux en réparation des conséquences d'une particulière gravité qu'il subit du fait de la dissolution du mariage soit lorsqu'il était défendeur à un divorce prononcé pour altération définitive du lien conjugal et qu'il n'avait lui-même formé aucune demande en divorce, soit lorsque le divorce est prononcé aux torts exclusifs de son conjoint./ Cette demande ne peut être formée qu'à l'occasion de l'action en divorce”. El artículo 1792 del código de Portugal prescribe lo siguiente: "(Reparação de danos não patrimoniais) 1. O cônjuge declarado único ou principal culpado e, bem assim, o cônjuge que pediu o divórcio com o fundamento da alínea c) do artigo $1781^{\circ}$, devem reparar os danos não patrimoniais causados ao outro cônjuge pela dissolução do casamento./ 2. O pedido de indemnização deve ser deduzido na própria ação de divórcio”. El artículo 351 del código de Perú dispone que "(s)i los hechos que han determinado el divorcio comprometen gravemente el legítimo interés personal del cónyuge inocente, el juez podrá concederle una suma de dinero por concepto de reparación del daño moral”. El artículo 288.4 del código de México establece que “(c)uando por el divorcio se originen daños o perjuicios a los intereses del cónyuge inocente, el culpable respondera de ellos como autor de un hecho ilícito". El artículo 144 del Código de Familia de Bolivia señala lo siguiente: "(Resarcimiento). Independientemente, el cónyuge culpable puede ser condenado al resarcimiento del daño material y moral que haya causado al inocente por la disolución del matrimonio".

${ }^{65}$ Severín (2008 a), p. 136. 


\section{LOS DERECHOS FUNDAMENTALES DE LOS CÓNYUGES}

Otro argumento para negar lugar a la indemnización por las consecuencias de la infracción de deberes matrimoniales se relaciona con el respeto de los derechos fundamentales de los cónyuges, que en un amplio espectro de casos podría quedar en entredicho de considerarse procedente el mencionado resarcimiento. En efecto y a modo de ejemplo, de imponerse responsabilidad civil al infractor, se le estaría obligando indirectamente - para no tener que resarcir a su consorte- a vivir en el hogar común, a la fidelidad o a socorrerlo. Ello iría, entre otros, contra los derechos a la libertad, al libre desarrollo de la personalidad y, en su caso, a la integridad psíquica $^{66}$. Una imposición como esta sería particularmente grave en casos de crisis conyugal, sobre todo si es insalvable, porque en este tipo de supuestos el incumplimiento de los referidos deberes deriva, precisamente, de la fractura irreversible del matrimonio, debiendo considerarse dicho incumplimiento, por tanto, como una conducta normal. En efecto, en caso de crisis conyugal no resulta inhabitual que las personas abandonen el hogar común o mantengan relaciones sexuales con terceros.

La anterior idea se ve ratificada por el artículo 33 de la Ley $\mathrm{N}^{\mathrm{o}} 19.947$, de 2004, que establece que, en caso de separación, se suspenden algunos deberes conyugales. Así acontece, lógicamente, con el de cohabitación, en relación con el cual, adicionalmente, el artículo 133 del Código Civil autoriza a los cónyuges a vivir en otro lugar en caso de circunstancias graves. Otro tanto ocurre con el deber de fidelidad, respecto del cual, además, el artículo 26 (2) de la Ley $\mathrm{N}^{\circ}$ 19.947, de 2004, prescribe que “(n)o podrá invocarse el adulterio cuando exista previa separación de hecho consentida por ambos cónyuges”. De este modo, el ordenamiento jurídico tolera el incumplimiento de los deberes conyugales para proteger los derechos fundamentales de quienes debían observarlos.

En términos prácticos, la precedente constatación se vislumbra con particular fuerza en el caso del deber de convivencia ${ }^{67}$. En efecto, de seguirse la tesis de la resarcibilidad, en caso de infringirse dicho deber ante un conflicto conyugal, el consorte que abandona el hogar tendría que indemnizar al otro pese a desplegar una conducta que normalmente las personas llevan a cabo en situaciones como aquella y que responde al soberano ejercicio de su derecho a vivir donde estime conveniente y a su libertad de movimiento. Como es obvio, esta problemática se aprecia con mayor intensidad en caso de crisis conyugal irreversible, en que el abandono del hogar común constituye su lógica consecuencia, siendo,

${ }^{66}$ Martín-Casals y Ribot (2011), p. 541; López de la Cruz (2010), p. 16.

${ }^{67}$ Ramos (2005), p. 129. 
por lo demás, en multitud de supuestos, la única alternativa para evitar su profundización, así como atentados a los derechos fundamentales de quien se ausenta del hogar marital. Baste pensar en las víctimas de violencia doméstica, que muchas veces hacen dejación del hogar familiar para trasladarse a vivir a otro, decisión que no solo se justifica en el pleno ejercicio de su libertad, sino también en el propósito de evitar continuar sometidas a malos tratos. Si el derecho optara por imponer una indemnización al cónyuge que decide abandonar el hogar común, enviaría una nociva señal al que está en trance de hacerlo por estar fracturada la vida conyugal, al incentivarlo a permanecer en dicho lugar contra su voluntad, con las nefastas consecuencias que esto podría acarrear no solo para él, sino también, en su caso, para los hijos. En síntesis, el derecho no tiene forma de compeler al cónyuge que abandona el hogar común a retornar a él, quedando su regreso entregado a su exclusiva voluntad. En este sentido, cabe tener en cuenta que el artículo 133 del Código Civil establece que un cónyuge puede decidir no vivir en el hogar común cuando "le asistan razones graves para no hacerlo". Entre estas, aparte, por supuesto, de las hipótesis de violencia intrafamiliar, se encuentran las crisis conyugales, sobre todo las irreversibles, a las que sin duda puede catalogarse de "razones graves" para no vivir en el hogar conyugal ${ }^{68}$.

118 Al margen de los deberes referidos expresamente por la ley, como el de cohabitación, cabe pensar en otros ejemplos en que imponer a un cónyuge indemnización por infracción de un deber matrimonial atentaría contra sus derechos humanos. Así acontecería si se le impusiera por negarse a cumplir el deber de tener relaciones sexuales con su consorte ("débito conyugal"). De obligársele al resarcimiento se vulneraría su derecho a la libertad sexual al imponérsele -indirectamente- el mantenimiento de relaciones sexuales pese a no quererlo ${ }^{69}$.

${ }^{68}$ Ramos (2005), pp. 128s.

${ }^{69}$ Un caso en que se debatió acerca del incumplimiento de esta faceta del deber de fidelidad fue el fallado por el Tribunal de Milán el 10 de febrero de 1999, que sentenció, ante la reconvención de la cónyuge frente a la demanda del marido, que no debía indemnizarla por los daños psíquicos que habría padecido por negarse aquel a mantener relaciones sexuales por más de treinta años de matrimonio, salvo en muy pocas ocasiones y de manera incompleta. El tribunal tuvo en cuenta que la cónyuge podría haber solicitado el divorcio muchos años antes, que padecía un síndrome ansioso-depresivo por su situación matrimonial desde hace bastante tiempo (sin que se hubiera percatado de él con la separación -como sostuvo-) y que -contrariamente a lo que adujo- la presión de los familiares de su consorte no había sido suficiente para evitar que accionara. Así, se descarta la indemnización porque el daño padecido por la mujer o su agravación se debió a que no quiso demandar el divorcio antes, no dándose el presupuesto de la causalidad. Sentencia referida en De Verda y Chaparro (2012), pp. 123s.; Novales (s/a), p. 127; Zambrano (2014), pp. 36s.; LóPEz DE la Cruz (2010), pp. 21s. El Tribunal Supremo de Portugal, en 


\section{Dificultad PARA VERIFICAR El CUMPLIMIENTO DE LOS REQUiSITOS}

DE LA RESPONSABILIDAD CIVIL EN CASO DE INFRACCIÓN

\section{DE DEBERES CONYUGALES}

Luego, la verificación del cumplimiento de los presupuestos que harían procedente la indemnización por las consecuencias de la infracción de deberes conyugales resulta altamente dificultosa. Me refiero, básicamente, a los requisitos daño, causalidad e imputabilidad ${ }^{70}$.

\section{Daño y causalidad}

Para que haya lugar a indemnización por las consecuencias de la infracción de deberes conyugales debe comprobarse la producción de un daño, sin que baste la sola infracción. Así, la acreditación de una causal de divorcio, como la infidelidad, no desencadena automáticamente indemnización, siendo indispensable al efecto la prueba del menoscabo ${ }^{71}$. Según se sabe, el detrimento desencadenante de responsabilidad civil debe cumplir determinados requisitos.

En primer término, dicho detrimento debe implicar la lesión de un interés jurídicamente protegido, de manera que en relación con la vulneración

sentencia de 21 de junio de 1991, concedió indemnización a la cónyuge por infracción de los deberes matrimoniales por el marido, que nunca pudo tener relaciones sexuales con ella, habiendo descubierto, adicionalmente, que aquel era homosexual. Un caso similar es el fallado por la Corte de Casación italiana el 10 de mayo de 2005. Sentencias referidas en LÓPEZ DE LA CRUZ (2010), pp. 17s. y 20s. En nuestro medio, en Marín con Valenzuela (2015) la actora solicitó indemnización por los daños causados por el demandado al haber terminado su matrimonio por divorcio en virtud de la causal "conducta homosexual" (artículo $54 \mathrm{n}^{\circ} 4$ de la Ley $\mathrm{N}^{\mathrm{o}} 19.947$, de 2004). El caso se resolvió sobre la base de una consideración formal: la Corte de Apelaciones de Santiago confirmó la sentencia del tribunal de primera instancia, que se declaró incompetente porque el demandado no residía en Chile. La Corte Suprema desechó el recurso de casación en el fondo por incumplimiento de sus presupuestos.

${ }^{70}$ De Verda y Chaparro (2012), p. 118; Sáinz-Cantero y Pérez (2012), pp. 21-23; TAPIA (2016), p. 170. La sentencia de la Corte de Apelaciones de Talca pronunciada en Abarca con González (2012), señala lo siguiente: "Que lo dicho anteriormente no significa que todo daño sufrido en el matrimonio dé origen, por su sola existencia, a la procedencia de una reparación, sino que deben configurarse los presupuestos exigidos por la responsabilidad civil (existe discusión para los que aceptan la procedencia, acerca de si ésta debe regirse por el estatuto de responsabilidad civil contractual o extracontractual sin embargo, como afirma la doctrina mayoritaria en la actualidad, tal distinción ha venido perdiendo importancia). En consecuencia, se exige una conducta antijurídica, factor de atribución, dolo o culpa, un nexo causal y, la existencia del daño".

${ }^{71}$ Sáinz-Cantero y Pérez (2012), pp. 45s.; Zambrano (2014), pp. 33s.; Ramos (2014), p. 260. 
de deberes matrimoniales debe determinarse si las perturbaciones que genere pueden considerarse lesivas de un interés de aquella índole ${ }^{72}$. En este sentido, existirán casos en que resulte claro que no se ha menoscabado un interés legítimo y en los que las perturbaciones acaecidas, por tanto, no deban indemnizarse, como serían, por ejemplo, las padecidas por la infidelidad de un cónyuge cuando el afectado también ha sido infiel ${ }^{73}$.

Luego, el daño indemnizable debe ser de magnitud suficiente o anorma $I^{4}$. Se trata de un presupuesto también exigible en el derecho de familia, de manera que en este ámbito solo se debe resarcir el menoscabo cuya envergadura fuerce al derecho a reaccionar imponiendo la obligación de indemnizar. Así, las consecuencias de la infracción de deberes matrimoniales, aun cuando puedan afectar a un cónyuge, solo deben indemnizarse si son de magnitud suficiente o anormal, debiendo ser soportadas las que no lo sean por aquel como tantas otras perturbaciones, pesares, molestias, disgustos o incomodidades que se producen en la vida de relación ${ }^{75}$.

La exigencia de anormalidad del daño indemnizable puede extraerse en el ámbito del derecho de familia de los artículos 26 y $54 \mathrm{n}^{\circ} 2$ de la Ley $\mathrm{N}^{0} 19.947$, que permiten solicitar la separación o el divorcio, no ante cualquier atentado a los deberes matrimoniales, sino exclusivamente en caso de una infracción de determinada envergadura: una falta que 120 constituya una violación grave de los deberes y obligaciones que impone el matrimonio y torne intolerable la vida en común; con el agregado de que, en caso de infidelidad o abandono de hogar, debe haber, para que haya lugar al divorcio, aparte de gravedad, reiteración. Así, el legislador contempla la suspensión o término de la vida conyugal únicamente ante eventos particularmente significativos, lo que implica que solo en estos casos asume que la respectiva conducta es socialmente desvalorada. En la misma línea, el artículo 11 de la Ley $\mathrm{N}^{\mathrm{o}} 20.066$, de 2005, contempla la indemnización solo ante daños especialmente graves: los que afecten la vida o integridad física o psíquica de determinados sujetos, mas no ante cualquier perturbación acaecida en la vida familiar.

${ }^{72}$ TAPIA (2016), pp. 175s.; Zambrano (2014), p. 34.

${ }^{73}$ De Verda y Chaparro (2012), p. 148.

${ }^{74}$ Barros (2006), pp. 219ss.; Vicente (2002), pp. 210ss.

${ }^{75}$ De Verda y Chaparro (2012), pp. 111 y 122 (señalan que la indemnización debería proceder ante incumplimientos “graves o reiterados"); SÁinz-CANTEro y Pérez (2012), pp. 21-23; RAMOs (2014), p. 260; BRAVO (2015) p. 261. En el derecho comparado destacan los artículos 266 del Código Civil francés, que establece, respecto del divorcio y la separación, la obligación de indemnizar las consecuencias de especial gravedad producidas por la ruptura matrimonial reprochable a uno de los consortes; y 351 del de Perú, que dispone que podrá haber lugar a indemnización si se compromete gravemente el legítimo interés personal del cónyuge inocente. 
Las citadas normas dan cuenta de que no todas las consecuencias de la vulneración de deberes conyugales se consideran intolerables por el legislador y, por tanto, indemnizables, sino solo las especialmente relevantes o anormales. Así, no deben resarcirse las perturbaciones no constitutivas de un daño anormal, como el inmediato y típico desasosiego que sigue al incumplimiento de un deber matrimonial o la afectación del interés en el mantenimiento del matrimonio y sus beneficios ${ }^{76}$. Como es obvio, la ausencia de anormalidad de las perturbaciones generadas por la infracción de deberes conyugales será más frecuente en caso de crisis matrimonial (sobre todo irreversible), ya que las conductas que en otro contexto se considerarían intolerables, suelen estimarse normales en supuestos de fractura de la vida familiar. Por el contrario, las consecuencias de la vulneración de deberes conyugales deberán resarcirse si configuran un delito o falta penal, un atropello a derechos fundamentales o, en general, un menoscabo de magnitud suficiente ${ }^{77}$. Esto se debe a que serían indemnizables en cualquier contexto ${ }^{78}$.

Conforme a lo señalado y a modo de ejemplo, las inmediatas y típicas perturbaciones, pesares, molestias, disgustos o incomodidades provocadas por la infracción del deber de fidelidad no bastan para hacer procedente la indemnización, siendo necesaria al efecto la concurrencia de consecuencias constitutivas de un daño de magnitud suficiente o anormal ${ }^{79}$. Se

${ }^{76}$ Sáinz-Cantero y Pérez (2012), p. 58.

${ }_{77}$ Ejemplos de estas tres hipótesis en Barcia y Rivera (2015), pp. 42-46; VARgaS (2009), pp. 179ss.

${ }^{78}$ Respecto de la indemnizabilidad de los daños ocasionados entre cónyuges solo cuando el menoscabo es anormal, véanse MARín (2006 b), pp.159s.; y VARGAS (2009), pp. 244 , quien señala que aquéllos "se encuentran expuestos a mayores conflictos que pueden acarrear ciertas molestias o desavenencias, pero que en ningún caso constituyen daños o perjuicios a derechos subjetivos o intereses jurídicamente protegidos".

${ }^{79}$ TAPIA (2016), pp. 176-178; SEverín (2008 a), p. 137. El Tribunal Supremo alemán ha fallado que los padecimientos derivados del adulterio no son indemnizables, salvo que medie dolo - FERRER (2001), p. 16-, como en caso de ocultación de paternidad (sentencia de 19 de diciembre de 1989 -véase BARCIA y Rivera (2015), pp. 33s.-). El Tribunal de Roma, en sentencia de 17 de septiembre de 1989, falló que la sola infidelidad no basta para que proceda indemnización -referida en LÓPEz DE LA CRUZ (2010), p. 21-. El Tribunal de Milán, en sentencia de 22 de noviembre de 2002, estimó que el sufrimiento del marido por la infidelidad (oculta) de la cónyuge no es indemnizable al no presentar una gravedad y lesividad especialmente grave (referida en DE Verda y Chaparro -2012-, p. 147). También lo ha señalado el Tribunal Supremo español, en sentencias de 22 y 30 de julio de 1999. En estos casos, eso sí, aparte de la infidelidad, hubo ocultación de la paternidad por la cónyuge. Consultar MARín (2006 b), pp. 171-174 (quien, pese a su posición general a favor de la indemnización por infracción de deberes conyugales, parece entender que la mera infracción del deber de fidelidad no debe resarcirse, sin perjuicio de que deba serlo en caso de daño injusto, como ocurre en los supuestos de ocultación de la paternidad -p. 177-); 
trata de una conclusión que opera con mayor fuerza en contextos de crisis conyugal, sobre todo irreversible, en que no resulta anormal el mantenimiento de relaciones sexuales con terceros. A la inversa, las consecuencias asociadas a la infracción del deber de fidelidad serían indemnizables si vulneran los derechos fundamentales del cónyuge víctima o atentan anormalmente contra el deber general de no dañar (nunca podrán configurar un delito penal porque el adulterio fue derogado como tal $)^{80}$. Esto podrá ocurrir, por ejemplo, cuando, tras una infidelidad, medie una ocultación de paternidad, que podrá dar lugar a indemnización por los perjuicios derivados de la ocultación y por los provenientes de la manutención del hijo ${ }^{81}$; cuando, a consecuencia de una infidelidad, uno de los cónyuges

Romero (2009), pp. 41ss.; Sáinz-CANTERo y Pérez (2012), pp. 7s.; MendozA (2011), pp. 54ss. En sentencia de 5 de septiembre de 2007 la Audiencia Provincial de Valencia dictaminó que la sola infidelidad no da lugar a indemnización, advirtiendo que la única consecuencia contemplada por la legislación es la terminación del matrimonio. En sentido similar se pronunció la Audiencia Provincial de León el 10 de noviembre de 2010. De Verda y ChAPARRo (2012), pp. 153s. (nota 356). A los casos nacionales me refiero más adelante.

${ }^{80}$ Respecto de las diversas posibilidades de infracción del deber de fidelidad, así como de las eventuales soluciones ante ella, véase Novales (2007), pp. 201ss.

${ }^{81}$ Severín (2008 a), pp. 138s. Un interesante caso constitutivo de un supuesto de este tipo es el fallado por el Tribunal Supremo español el 10 de junio de 2008, que declaró inadmisibles los recursos extraordinario y de casación deducidos por los demandados, y de casación interpuesto por el actor, confirmando, así, el fallo de segunda instancia de la Audiencia Provincial de Valencia, de 2 de noviembre de 2004. Los hechos fueron los siguientes: un hombre demandó a su cónyuge porque tres de los cuatro hijos del matrimonio, que habían sido reconocidos por el actor, resultaron no ser suyos, sino de un tercero (que también fue demandado), con el cual la mujer había mantenido una relación extramarital, teniendo pleno conocimiento las dos personas, desde un principio, de esta situación. El tribunal de primera instancia condenó solidariamente por responsabilidad extracontractual a los demandados a pagar una indemnización al actor por el daño moral padecido a consecuencia de la pérdida del vínculo biológico con los hijos; pero no por la infracción del deber de fidelidad, que no se consideró susceptible de generar resarcimiento. El tribunal de segunda instancia suscribió el planteamiento, sin perjuicio de que aumentó el monto de la indemnización por la dolosa ocultación de la paternidad. Otro caso de ocultación (dolosa) de paternidad resuelto en términos similares es el fallado por la Audiencia Provincial de León el 30 de enero de 2009. Un caso parecido es el resuelto por la misma Audiencia el 2 de enero de 2007. Eso sí, en primera instancia la demanda del actor (a quien se había hecho creer que los tres hijos del matrimonio eran suyos, no siéndolo el último) fue desechada íntegramente. El tribunal de segunda instancia dio lugar a la indemnización por responsabilidad extracontractual por ocultación dolosa de la paternidad por la mujer y el tercero (no por la pérdida del vínculo biológico), pero con expresa prevención de que, atendida la especialidad del derecho de familia, el daño moral ocasionado por la infidelidad no es indemnizable. Aparte de los casos de ocultación dolosa de la paternidad, pueden presentarse supuestos negligentes, como aquellos en que la cónyuge desconoce si el padre del hijo es su marido, como el fallado por la Audiencia Provincial de Barcelona el 16 de enero de 2007, que dio lugar a la indemnización. Un 
haya contraído una enfermedad venérea que contagia al otro ${ }^{82}$; o cuando, luego de aquella, se materialice un atentado al honor del consorte (v. gr., en virtud de la divulgación deliberada del engaño) ${ }^{83}$.

Lo mismo puede concluirse respecto de los deberes de socorro y cohabitación. Así, no todas las perturbaciones derivadas de una falta de auxilio o del abandono del hogar común deben resarcirse. Nuevamente, se trata de una conclusión que opera con particular intensidad en el contexto de una crisis conyugal, sobre todo irreversible, en que no resulta anormal la ausencia de auxilio o la dejación del hogar marital. Por el contrario, dichas perturbaciones deberían resarcirse si constituyen un daño anormal, como si se deja al cónyuge en circunstancias en que la falta de acompañamiento afecte significativamente su salud o integridad, por ejemplo, por encontrarse gravemente enfermo, hallándonos en esta hipótesis ante un caso de infracción de derechos fundamentales y del deber general de no da-

examen de estos y otros casos en VARgas (2009), pp. 203-217; De Verda y Chaparro (2012), pp. 151ss.; Marín (2006 b), pp. 175ss.; Romero (2009), pp. 50ss.; Mendoza (2011), pp. 56ss.

${ }^{82}$ Severín (2008 a), pp. 138s. En España, la Audiencia Provincial de Baleares, el 14 de septiembre de 2001, condenó a un hombre casado por responsabilidad extracontractual por haber infectado a su cónyuge con sida, habiéndole ocultado que, tanto con anterioridad al matrimonio como vigente este, había mantenido relaciones sexuales con hombres y mujeres, lo cual se consideró que constituía negligencia, por haberse colocado dentro de un grupo de riesgo y no utilizar preservativo con su cónyuge (sentencia comentada por VARGAS -2009-, pp. 217-219). En nuestro país, la sentencia de la Corte de Apelaciones de Talca pronunciada en Abarca con González (2012), descartó la responsabilidad civil por transmisión del virus del papiloma humano del marido supuestamente infiel a la cónyuge, pero por no comprobarse la causalidad. El fallo señala lo siguiente: "En la especie, no ha podido comprobarse supuestos que descartan en su esencia que pueda darse por establecida la relación de causalidad entre las infidelidades (verdaderas o conjeturadas del marido) y el contagio de la mujer del virus del papiloma humano, para ello sería necesario descartar que la misma mujer no hubiera sido portadora del mismo virus con anterioridad (gran porcentaje de los adultos lo portan), que el marido no lo hubiera contraído antes de contraer matrimonio (caso en el cual la infidelidad no sería la causa del daño), entre varias otras hipótesis posibles de imaginar, que hacen imposible dar por establecido el nexo causal entre las supuestas infidelidades del marido y el cáncer padecido por su mujer".

${ }^{83}$ Véase Sáinz-Cantero y Pérez (2012), pp. 228s. Un ejemplo de infidelidad de este tipo es el caso fallado por la Sala II de la Cámara de Apelaciones Civil y Comercial de Mar del Plata (Argentina, 4 de abril de 1997), que dio lugar a la indemnización por considerar el adulterio del marido de gran envergadura y con escandalosa publicidad (véase SAMBRIzzI -2001-, p. 155). Cierta jurisprudencia comparada, como la francesa, se inclina por conceder indemnización por los padecimientos provocados por la sola infidelidad. Otra (con la que concuerdo) considera que los sufrimientos provocados por la sola infidelidad no son resarcibles, exigiendo para que lo sean que junto a ellos concurra un daño significativo, como el derivado de la ocultación de paternidad (caso de la jurisprudencia española) o de atentados al honor causados por una infidelidad pública (caso de la jurisprudencia italiana). De Verda y Chaparro (2012), pp. 146ss. 
ñar ${ }^{84}$. Incluso, si en un determinado evento se cumplen los presupuestos de la omisión de socorro contemplados por el artículo $494 \mathrm{n}^{\circ} 14$ del Código del ramo, podría configurarse un ilícito penal, que también debería dar lugar a resarcimiento ${ }^{85}$.

Similares reflexiones cabe aplicar en relación con la infracción del deber de protección, de manera que no todas las perturbaciones que genere deben resarcirse. Una vez más, se trata de una conclusión que opera con especial potencia en el contexto de una crisis conyugal, sobre todo si es irreversible, sin que pueda considerarse anormal toda conducta que vaya contra el referido deber. Por el contrario, las perturbaciones provocadas por su vulneración deberían resarcirse si constituyen un daño anormal, lo que acontecerá, por ejemplo, si se abandona al cónyuge que se encuentra gravemente enfermo (en que podrá haber un atentado a sus derechos fundamentales, al deber general de no dañar o, incluso, un ilícito penal). Sería el caso, asimismo, de la violencia intrafamiliar ${ }^{86}$, que puede implicar una vulneración del derecho fundamental a la salud o al deber general de no dañar o, incluso, constituir un ilícito penal, como el de lesiones, maltrato habitual o uno de índole sexual ${ }^{87}$. En este sentido, el artículo 11 de la Ley $\mathrm{N}^{\mathrm{o}} 20.066$, de 2005, contempla la indemnización pero solo ante menoscabos de determinada envergadura: los que afecten la vida o

${ }^{84}$ De Verda y Chaparro (2012), pp. 127-129 y 139-142. Entre otros, se refieren estos autores (p. 140) al caso fallado por el Tribunal de Milán el 4 de junio de 2002, que condenó al marido a indemnizar a la cónyuge porque, a pesar de continuar viviendo formalmente con ella, no la auxilió afectiva, psicológica y materialmente durante su embarazo ni preocupó de su hijo al nacer, lo que provocó en aquella una depresión grave. En el texto pueden consultarse abundantes casos españoles, italianos y franceses de incumplimiento de los deberes de cohabitación, asistencia y socorro. Un caso similar es el fallado por el mismo tribunal el 24 de septiembre de 2002, que condenó al marido a indemnizar a su consorte por haberse despreocupado totalmente de ella durante el embarazo, provocándole una depresión (referido por Zambrano -2014-, pp. 38s.). Otro interesante ejemplo es el caso fallado por la Sala I de la Cámara I Civil y Comercial de San Isidro (Argentina, 13 de mayo de 1998), que dio lugar a la indemnización por considerar que el abandono del hogar por el marido provocó un daño moral a su cónyuge al dejarla enfrentar sola los reclamos y embargos de los acreedores (referido en SAMBRIZZI -2001-, pp. 155s.). En una línea similar se inserta la sentencia del Tribunal de Florencia, de 13 de junio de 2000, que impuso indemnización al marido por el daño biológico padecido por su cónyuge a consecuencia de no cumplir con el deber de asistencia al no auxiliarla y negarse a vivir con ella a pesar de padecer una invalidante enfermedad mental, que empeoró por el abandono y la falta de tratamiento apropiado (véanse LóPEZ DE LA CRUZ -2010-, p. 22; ZAMBrANO -2014-, p. 37).

${ }^{85}$ Respecto de las diversas posibilidades de infracción del deber de socorro y ayuda mutua, así como de las eventuales soluciones ante ella, véase Novales (2007), pp. 293ss.

${ }^{86}$ Severín (2008 a), p. 137.

${ }^{87}$ Respecto de las diversas posibilidades de infracción del deber de respeto y protección, así como de las eventuales soluciones ante ella, véanse DE VERDA y CHAPARRO (2012), pp. 131ss.; Novales (2007), pp. 163ss.; Marín (2006 b), p. 153. 
integridad física o psíquica de ciertos individuos, mas no ante cualquier perturbación de la vida familiar. Otro ejemplo lo constituyen los supuestos de atentados al honor y la intimidad (insultos y difamación, por ejemplo) ${ }^{88}$.

La jurisprudencia nacional ha reconocido la exigencia de un daño de magnitud suficiente o anormal para dar lugar a la indemnización de las consecuencias de la infracción de deberes conyugales. Si se revisan detenidamente las sentencias sobre el particular, puede constarse que los tribunales solo ordenan la reparación de determinado tipo de consecuencias, mas no de todas las provocadas por dicha infracción. En efecto, no imponen el resarcimiento de las perturbaciones, angustias, molestias, disgustos o incomodidades inmediatas y típicas producidas por la mencionada infracción, pero sí si da lugar a consecuencias constitutivas de un daño anormal. Por esto es que, en su caso, conceden indemnización por los detrimentos a la integridad física o psíquica generados por la violencia doméstica $^{89}$, pero no por las perturbaciones inmediatas y típicas provocadas por la infracción de deberes conyugales, como el de fidelidad (en que no se resarce la aflicción producida por el engaño), salvo que vaya acompañada de conductas generadoras de daños anormales, por ejemplo, ocultación de paternidad o transmisión de enfermedades venéreas ${ }^{90}$.

88 Véanse Ramos (2014), p. 261; De Verda y Chaparro (2012), pp. 132-139. Un interesante caso referido por estos últimos es el fallado por la Corte de Apelaciones de Versalles el 28 de octubre de 2010, que condenó al marido a indemnizar a su cónyuge por enviar un correo electrónico a la dirección de América de la empresa en que ella laboraba, señalando que su ascenso se debió a que tenía una relación sexual con su jefe.

${ }^{89}$ Por ejemplo, Pinto con Rojas (2014), en que la Corte Suprema desecha el recurso de casación en el fondo deducido contra la sentencia de la Corte de Apelaciones de la Serena (2014), que condenó al marido a indemnizar a la cónyuge por repetidos actos de violencia intrafamiliar. También puede consultarse Ruiz con Cazes (2014), en que la Corte de Apelaciones de Santiago confirmó la sentencia de primera instancia, que condenó al demandado a indemnizar a su excónyuge por violencia intrafamiliar ocurrida durante el matrimonio, si bien con la declaración de que la acción estaba prescrita respecto de determinados hechos, ratificando la condena en relación con un episodio. La Corte Suprema (2015) rechazó el recurso de casación en el fondo por no cumplirse sus presupuestos. Otro ejemplo es Soto con González (2011), en que la Corte de Apelaciones de Valparaíso, revocando la sentencia de primera instancia, que había declarado el divorcio e impuesto compensación económica, pero rechazado la solicitud de indemnización por estar prescrita, condenó adicionalmente al marido a resarcir a la cónyuge por violencia intrafamiliar. La Corte Suprema, considerando que los tribunales de familia no son competentes para conocer demandas indemnizatorias, anuló el fallo, dictando sentencia de reemplazo. También puede consultarse Fuentes con Palma (2016), en que la Corte de Apelaciones de Chillán confirmó la sentencia de primera instancia, que impuso indemnización por violencia intrafamiliar al demandado. Respecto de la responsabilidad civil por violencia intrafamiliar, véanse ZAIKOSKI (2015), principalmente las pp. 145ss.; Bonilla (2012), pp. 178ss.

${ }^{90} \mathrm{Si}$ bien en Chile no se han presentado muchos juicios sobre el particular, en otros ordenamientos -como el argentino- se vienen planteando abundantemente desde 
Un tercer requisito del daño indemnizable es que sea directo ${ }^{91}$. Esta exigencia está relacionada con el presupuesto de la causalidad/imputación objetiva, traducido en que el daño resarcible es el generado de manera inmediata, en un sentido jurídico, por la conducta del agente. También se trata de un presupuesto de difícil evaluación en caso de infracción de un deber matrimonial, sobre todo en el contexto de una crisis conyugal.Jurídicamente, es en extremo dificultoso reconducir a la conducta del infractor, directamente y con un aceptable nivel de certeza, las afectaciones padecidas por su consorte producto del incumplimiento de un deber matrimonial, principalmente en el marco de una crisis conyugal ${ }^{92}$. En la generalidad de los casos, dichas afectaciones no resultan conectables directamente con el incumplimiento de un deber de aquel tipo. En los supuestos de crisis matrimonial, las perturbaciones, angustias, molestias, disgustos o incomodidades que sufren los cónyuges a consecuencia de dicho incumplimiento provienen de diversos factores, siendo sumamente complejo concluir, por ejemplo, que derivan directamente de la infidelidad o el abandono del hogar común ${ }^{93}$. Esta constatación aparece con

hace tiempo (SAMbrizZI -2001-, pp. 148ss.). En nuestro medio puede citarse la sentencia pronunciada en De la Huerta con Cabezas (2016), en que la Corte de Apelaciones de Santiago confirmó la sentencia de primera instancia, que había condenado al pago de 126 una indemnización a la demandada por ocultar la paternidad del hijo al actor, denegando la demanda contra el tercero que participó en el adulterio de aquella. Por su parte, la sentencia de la Corte de Apelaciones de Talca pronunciada en Abarca con González (2012), descartó la responsabilidad civil por transmisión del virus del papiloma humano del marido supuestamente infiel a la cónyuge, pero no porque en abstracto un daño como este no deba dar lugar a resarcimiento, sino porque no se comprobó el requisito de la causalidad.

${ }^{91}$ Igualmente, al efecto de que la infracción de un deber conyugal (por ejemplo, del de fidelidad) pueda dar lugar a la separación judicial o al divorcio se debe comprobar una relación de causalidad directa entre la infracción y la intolerancia de la vida en común exigida por los artículos 26 y 54 de la Ley No 19.947, de 2004. Zambrano (2014), p. 32 (respecto del derecho italiano).

${ }^{92} \mathrm{Al}$ efecto de la construcción de la imputación objetiva en sede de familia se deben considerar los criterios generales que permiten determinarla en otros contextos: adecuación, riesgo -creado o incrementado-, riesgo general de la vida y fin perseguido por la norma. SÁInZ-CANTERo y Pérez (2012), pp. 148-151. Entre las escasas sentencias que se refieren al punto, la de la Corte de Apelaciones de Talca, pronunciada en Abarca con González (2012), señala que "(p)or un lado el hecho debe ser condictio sine qua non del daño, de modo que cada uno de los hechos que determinan su ocurrencia son considerados causa por este; por otro, entre el hecho y el daño debe haber una razonable proximidad" (considerando $13^{\circ}$ ).

${ }^{93}$ En el caso fallado por la Audiencia Provincial de León el 2 de enero de 2007, se sentenció que los daños morales padecidos por la cónyuge no derivan únicamente de la infidelidad, sino de una variedad de factores. En particular, en el conflictivo caso del incumplimiento del deber de fidelidad, una hipótesis que descarta la indemnización por falta de causalidad es la infidelidad recíproca. De Verda y Chaparro (2012), pp. 154 (nota 356) y 148. 
mayor fuerza en los casos de incumplimiento de un deber matrimonial por omisión, como podría ocurrir con el "débito conyugal". En síntesis, por lo general, las consecuencias de la infracción de un deber matrimonial no pueden considerarse causadas (directamente) por esta ${ }^{94}$.

En fin, una dificultad adicional consiste en que el daño indemnizable debe ser probado ${ }^{95}$. Así, ante la alegación en un caso concreto de que la vulneración del deber de fidelidad, cohabitación o socorro ha producido la afectación del derecho a la salud psíquica del cónyuge que demanda indemnización, este deberá probar la afectación (por ejemplo, con informes de especialistas), sin que le baste acreditar la vulneración. Además, deberá comprobar que la afectación está vinculada de manera inmediata con la conducta del infractor. Lógicamente, esto se entiende sin perjuicio de que en ocasiones el daño extrapatrimonial pueda presumirse ${ }^{96}$.

En síntesis, la sola infracción de un deber conyugal no debe dar lugar a indemnización, siendo necesario acreditar al efecto que ha producido un daño a un interés legítimo, que es anormal y directo ${ }^{97}$.

${ }^{94}$ Acerca del requisito de la causalidad en los daños en las relaciones de familia, véase SÁinz-Cantero y PÉrez (2012), pp. 129ss. En Chile, puede consultarse la sentencia de la Corte de Apelaciones de Talca pronunciada en Abarca con González (2012), en que se lee lo siguiente: “(...) que aun cuando nos inclinemos por la aceptación de la responsabilidad civil en el seno del matrimonio, de acuerdo con las reglas generales de todo sistema de responsabilidad, el daño producido debe ser el resultado natural de la conducta antijurídica e imputable de su autor, esto debe ser atribuible causal y normativamente a la conducta dolosa o culpable desplegada por el autor. En la especie, no ha podido comprobarse supuestos que descartan en su esencia que pueda darse por establecida la relación de causalidad entre las infidelidades (verdaderas o conjeturadas del marido) y el contagio de la mujer del virus del papiloma humano, para ello sería necesario descartar que la misma mujer no hubiera sido portadora del mismo virus con anterioridad (gran porcentaje de los adultos lo portan), que el marido no lo hubiera contraído antes de contraer matrimonio (caso en el cual la infidelidad no sería la causa del daño), entre varias otras hipótesis posibles de imaginar, que hacen imposible dar por establecido el nexo causal entre las supuestas infidelidades del marido y el cáncer padecido por su mujer”.

${ }^{95}$ De Verda y Chaparro (2012), pp. 119s.; Sáinz-Cantero y Pérez (2012), p. 231; Vargas (2009), p. 242. En este sentido, la Corte Suprema, en Pinto con Rojas (2014), señaló lo siguiente: "Séptimo: "Que en mérito de lo expuesto, más allá de las disquisiciones doctrinarias sobre la procedencia de la reparación por el incumplimiento de los deberes matrimoniales, en la especie se ha determinado la responsabilidad civil del demandado como consecuencia de acreditarse el deterioro emocional o psicológico que le ha causado a la actora fruto de sus conductas antijurídicas que han motivado el divorcio por culpa decretado respecto de las partes" (cursivas mías). Esta sentencia rechaza -por defectos de formulación- el recurso de casación en el fondo interpuesto contra la de la Corte de Apelaciones de La Serena de 3 de abril de 2014.

${ }^{96}$ Sáinz-Cantero y Pérez (2012), pp. 43s.

${ }^{97}$ Buen ejemplo de rechazo de una demanda indemnizatoria por falta de prueba de los presupuestos del daño es el caso fallado por la sala J de la Cámara Nacional en lo Civil 


\section{Imputabilidad}

Otro requisito de la responsabilidad civil cuya evaluación es compleja en los supuestos de infracción de un deber conyugal es la imputabilidad, ya que resulta altamente dificultoso concluir que las consecuencias de dicha infracción son atribuibles a una conducta dolosa o negligente, sobre todo en el contexto de una crisis matrimonial. En sentido técnico-jurídico, no resulta sencillo calificar las conductas que generan dichas consecuencias como deliberadas o descuidadas, siendo en extremo difícil afirmar, por ejemplo, que la infidelidad o el abandono de hogar constituyen comportamientos dolosos o negligentes ${ }^{98}$.

Como sea, por lo que atañe al dolo, existe consenso en que todo comportamiento de un cónyuge en que concurra y genere un daño de magnitud suficiente y directo en los intereses del otro, debe dar lugar a indemnización. De este modo, en particular, si se infringe un deber matrimonial con el propósito de lesionar intereses del cónyuge y este resulta dañado, debería haber resarcimiento ${ }^{99}$. Es el caso, por ejemplo, de los supuestos de violencia intrafamiliar ${ }^{100}$.

En cuanto a la culpa, hay que tener en cuenta que al efecto de su configuración deben sopesarse diversos factores, como la falta de diligencia

de Argentina (31 de mayo de 2000) que, aun cuando acogió la solicitud de divorcio por adulterio de la demandante, desechó la de resarcimiento de los daños que habría padecido por el adulterio y abandono del hogar del marido entre 1980 y 1996 (año de la demanda), tiempo en el cual otorgó ayuda económica a su consorte; atendidas las características y extensión de la separación, la actitud de la cónyuge y la falta de acreditación de un perjuicio concreto distinto del provocado por el quiebre del matrimonio. Referido por Fleitas (2001), p. 180. En nuestro medio, puede consultarse la sentencia de la Corte de Apelaciones de Rancagua pronunciada en F. M., H. con V. C., M (2007) que, por no acreditarse los hechos, confirmó el rechazo de la reconvención de la actora, por la que -ante la demanda de divorcio por cese de la convivencia de su marido- solicitó la declaración de divorcio por culpa e indemnización por abandono de hogar y adulterio; si bien le concedió compensación económica.

${ }^{98}$ TAPIA (2016), pp. 171ss. En la sentencia de la Corte de Apelaciones de Santiago pronunciada en Prado Cuevas y Alcalde Ochagavía (2009) y otro, se expresa lo siguiente: "Vigésimo: (...) si se consideraran aplicables las normas del derecho común, tampoco sería posible considerar que el adulterio constituya un hecho ilícito civil. En efecto, si se tiene en consideración -que los delitos se caracterizan por el dolo y los cuasidelitos por la culpa- resulta en extremo dificultoso concebir que un adulterio se haya cometido por uno de los cónyuges con el propósito único y deliberado de causar daño al otro cónyuge, como así también, resulta difícil de imaginar un adulterio cometido simplemente por culpa o negligencia. El adulterio, como fenómeno sociológico de la humanidad, no puede encuadrarse bajo los parámetros de la responsabilidad civil extracontractual".

${ }^{99}$ Ferrer (2001), p. 9; Valenzuela (2012), p. 253.

${ }^{100}$ ZAIKosKi (2015), pp. 144 y 146. 
y, conectada con ella, la previsibilidad, que en el terreno de las relaciones de familia presentan peculiaridades ${ }^{101}$.

Considerando lo anterior, es indiscutible que la imputabilidad debe evaluarse a la luz de las particularidades de las relaciones de familia ${ }^{102}$, así como de la específica dinámica y forma en que frecuentemente se comportan los individuos en su vida marital ${ }^{103}$. De esta suerte, debe tenerse presente que en este ámbito las personas suelen comportarse de manera muy distinta a como lo hacen en sus relaciones sociales y comerciales, razón por la cual el estándar de conducta que debe servir de parámetro de comparación no ha de ser el que típicamente se tiene a la vista en dichas esferas, en que los individuos se desempeñan de forma menos espontánea, sino uno inferior ${ }^{104}$. Naturalmente, la evaluación culpabilística deberá hacerse con particular celo en el escenario en que mayormente se incumplen los deberes matrimoniales, esto es, en los supuestos de crisis conyugal (sobre todo si es irreversible), en que la forma de comportarse de las personas presenta peculiaridades completamente distintas de las que presenta en otros contextos. Así, como la vulneración de deberes matrimoniales suele materializarse en el marco de una crisis conyugal, en una abundante cantidad de supuestos resultará en extremo difícil concluir que al cónyuge infractor le era exigible otra conducta, que debió observar un estándar mayor de diligencia o que el "buen padre" o "madre de familia" habría actuado de forma distinta. La dificultad emana de que en multitud de ocasiones una conducta de incumplimiento de deberes conyugales puede catalogarse como un comportamiento normal en una situación de crisis matrimonial.

Conforme a lo apuntado, las particularidades de la vida conyugal y principalmente de los contextos de crisis matrimonial, podrán derivar, respecto del consorte que causa un daño, en la configuración de una causal de justificación que obste a la antijuridicidad de su conducta e implique su exoneración de responsabilidad. Serían los casos de legítima defensa, estado de necesidad, ejercicio legítimo de un derecho y consentimiento del ofendido (respecto de derechos disponibles) ${ }^{105}$. Así, por ejemplo, en el caso particular del deber de fidelidad, podría constituir causa de exoneración

${ }^{101}$ Sáinz-Cantero y Pérez (2012), pp. 103ss.

${ }^{102}$ Sambrizzi (2001), p. 4.

${ }^{103}$ Marín (2006 b), p. 160.

${ }^{104}$ Para algunos, este estándar se aproxima a una culpa subjetiva y grave. Véanse Ferrer (2001), pp. 11s.; Marín (2006 b), p. 160; Valenzuela (2012), p. 253.

105 Sáinz-Cantero y PÉrez (2012), pp. 65ss. Lógicamente, en caso de sostenerse que las consecuencias de la infracción de un deber conyugal deben indemnizarse, las consideraciones relativas al comportamiento de las personas en supuestos de crisis matrimonial también deben tenerse en cuenta. 
de responsabilidad el engaño recíproco de ambos consortes ${ }^{106}$. Y en del cohabitación, el abandono del hogar común por un cónyuge motivado por el propósito de aminorar o sortear los efectos del conflicto familiar, sobre todo si mediante él escapa de los actos de violencia perpetrados en su contra o de sus hijos por su consorte ${ }^{107}$.

Naturalmente, habrá casos en que la particular dinámica conyugal no deba excluir la responsabilidad civil, como ocurre en los supuestos de violencia intrafamiliar ${ }^{108}$.

\section{Argumentos ADicionales}

Finalmente, existen argumentos adicionales contra la indemnización por las consecuencias de la infracción de deberes conyugales, traducidos en la posibilidad de que genere indeseados efectos sociales, como el desincentivo del matrimonio, la obstaculización del divorcio o la sobrecarga del aparato jurisdiccional.

En primer lugar, la consolidación de una jurisprudencia que diera lugar a indemnización por las aludidas consecuencias podría repercutir en que menos personas estuvieran interesadas en celebrar un matrimonio al poder 130 verse expuestas, aparte de a un juicio de divorcio, a la posibilidad de tener

${ }^{106}$ De Verda y Chaparro (2012), pp. 145 y 148. Otro interesante supuesto referido por estos autores (p. 148) es el fallado por la Corte de Apelación de Aix-en-Provence (Francia) que, por sentencia de 23 de noviembre de 2010, concluyó que la cónyuge no debe ser resarcida por la infidelidad de su marido en atención a que durante muchos años ejerció en el hogar común como vidente provocando incontables molestias a la familia y que dispensó innumerables malos tratos a su consorte.

${ }^{107}$ En relación con la evaluación de la culpabilidad en esta materia y teniendo en cuenta que el propósito de este trabajo no es tratar todos los asuntos conflictivos relacionados con ella, dejo planteadas en términos generales tres cuestiones adicionales, que dan cuenta de las muchas aristas problemáticas que presenta esta temática. Primero, atendida la dinámica de los conflictos familiares, en una gran cantidad de casos resultará altamente complejo individualizar y distribuir culpas, puesto que en muchas ocasiones la conducta de un cónyuge encuentra su causa en el particular ambiente familiar de que se trata. Segundo y vinculado con lo anterior, en multitud de ocasiones habría que determinar si debe operar la compensación de culpas (artículo 2330 del Código Civil), por ejemplo, ante infidelidades cometidas por ambos cónyuges. Por último, en estos casos debe determinarse si -en aplicación del artículo 2317 del Código Civil- ha de imponerse responsabilidad o no al tercero que participa con uno de los cónyuges en la conducta que ocasiona perturbaciones al otro (por ejemplo, a la persona que tiene relaciones sexuales con una mujer casada, cuando a ellas sigue un embarazo y ocultación de paternidad). Acerca de estas cuestiones, véanse De Verda y Chaparro (2012), pp. 148-150; Sáinz-Cantero y Pérez (2012), pp. 151ss.; TAPIA (2016), pp. 171ss.; SAMBRIZZI (2001), pp. 157-160.

${ }^{108}$ ZAIKOSKI (2015), p. 144. 
que resarcir a su cónyuge en caso de infringir deberes matrimoniales, a pesar de que esto acontezca en el marco de una crisis familiar, sobre todo si es irreversible. Si a esto se suma que puede tener la obligación de pagarle una compensación económica, el desincentivo para contraer matrimonio se incrementa, con lo que la tasa de nupcialidad podría continuar cayendo por el encarecimiento de los costos de aquel ${ }^{109}$.

En segundo término, la consolidación de una jurisprudencia como la mencionada podría traducirse en que las personas que pretenden finalizar su matrimonio mediante el divorcio evitaran hacerlo si arriesgan que se les imponga un resarcimiento por las consecuencias de la infracción de deberes conyugales, optando por mantener un vínculo irreversiblemente destruido ${ }^{110}$. Adicionalmente, en los países que han prescindido de la regulación del divorcio por causales, marcadamente caracterizado por un debate relativo a la culpabilidad del infractor, la discusión en términos de culpabilidad, propia de un juicio indemnizatorio, reintroduciría, subrepticiamente, el divorcio sanción ${ }^{111}$.

Luego, no cabe duda de que la aceptación de la responsabilidad civil por las referidas consecuencias podría provocar una sobrecarga de los tribunales al verse enfrentados a un excesivo aumento de la litigiosidad, representado por la deducción de un número inmanejable de demandas indemnizatorias para resolver asuntos domésticos sin una significativa trascendencia para el derecho, con el consiguiente indeseado efecto de que contarían con menos tiempo para dedicarse a las cuestiones auténticamente relevantes ${ }^{112}$.

Por último, cabe tener en cuenta que, considerando que asuntos de esta índole deben sustanciarse ante juzgados civiles, se presenta el inconveniente de que tribunales no especializados pueden resolver controversias propias del derecho de familia ${ }^{113}$.

\footnotetext{
${ }^{109}$ Ferrer (2001), p. 15.

${ }^{110}$ Tapia (2016), p. 167. En contra, Medina (2008), pp. 64s.

${ }^{111}$ Ferrer (2001), p. 15.

${ }^{112}$ Marín (2006 b), p. 162; Ferrer (2001), pp. 9 y 15.
}

${ }^{113}$ Entre los asuntos de competencia de los tribunales de familia, el artículo 8 de la Ley No 19.968, de 2004, no menciona la solicitud de indemnización. En Soto con González (2011), la Corte de Apelaciones de Valparaíso, revocando la sentencia de primera instancia, que había declarado el divorcio e impuesto compensación económica, pero rechazado la solicitud de indemnización por estar prescrita, condenó adicionalmente al marido a resarcir a la cónyuge por violencia intrafamiliar. La Corte Suprema, considerando que los tribunales de familia no son competentes para conocer demandas indemnizatorias, anuló el fallo, dictando sentencia de reemplazo. En sentido similar se pronunció la misma corte en Barrios con Espinoza (2008) ante una demanda en que el actor solicitó indemnización contra su ex cónyuge por haber demandado y obtenido dolosamente el pago de una pensión de alimentos a favor de una niña que no era hija suya. En sentido contrario, la 


\section{Conclusiones}

1. Existen múltiples argumentos para no dar lugar a la indemnización por las consecuencias de la infracción de deberes conyugales.

2. La improcedencia de la responsabilidad civil ante dichas consecuencias implica que, aun cuando gozan de juridicidad, cuentan con una restringida. Es decir, pese a que disfrutan de cierto grado de juridicidad, por estar tipificados y poder dar lugar su vulneración al divorcio o la separación judicial, no cuentan con un nivel máximo de juridicidad, limitándose esta a los referidos efectos, sin que las consecuencias de su incumplimiento deban dar lugar a indemnización.

3. En primer término, la juridicidad restringida de los deberes matrimoniales está avalada por la circunstancia de que, técnico-jurídicamente-, no son obligaciones. Esto se debe a que, básicamente y a diferencia de ellas, presentan una faceta moral que prima sobre la jurídica; y no admiten cumplimiento compulsivo en naturaleza. De ambos asertos deriva que las consecuencias de su incumplimiento, contrariamente a lo que sucede con el de las obligaciones, no dan lugar a indemnización.

4. En segundo lugar, la juridicidad restringida de los deberes conyugales está avalada por la especificidad de las sanciones del derecho de familia, que se traduce en que el ordenamiento jurídico contempla como efectos ante la infracción de los deberes conyugales el divorcio y la separación judicial, pero no la indemnización; en que consagra expresamente efectos patrimoniales en materia de derecho de familia e incluso la responsabilidad civil, pero no ante las consecuencias de aquella infracción; y en que cuando vinculó consecuencias patrimoniales a los deberes conyugales o a su vulneración, lo hizo expresamente, sin que haya mencionado la indemnización.

5 . En tercer lugar, la juridicidad restringida de los deberes matrimoniales se fundamenta en la protección de los derechos fundamentales de los cónyuges, en el sentido de que imponer a uno la obligación de resarcir al otro por infringirlos, sobre en todo en contextos de crisis, podría atentar contra el derecho a la libertad del primero al compelerlo indirectamente a cumplir con dichos deberes, como acontecería si se lo obliga a indemnizar en caso de infidelidad o abandono de hogar.

6 . En cuarto término, la juridicidad restringida de los deberes conyugales deriva de la dificultad para verificar el cumplimiento de los requisitos

Corte de Apelaciones de Concepción, en Peñaloza con Hebles (2008), consideró que los tribunales de familia tienen competencia para conocer de la solicitud de indemnización en este ámbito, revocando la sentencia de primera instancia, que había resuelto que no tienen. Comentada críticamente por Severín (2008 b). A favor de que estas cuestiones sean conocidas por los tribunales de familia, Herane (2007), p. 193. 
de la responsabilidad civil en caso de infracción, destacadamente, por una parte, del daño y la causalidad y, por otra, de la culpabilidad.

a) En cuanto al daño y la causalidad, hay que tener en cuenta que el menoscabo indemnizable debe ser de magnitud suficiente y directo. Así, no deben resarcirse las perturbaciones no constitutivas de un daño anormal, como el inmediato y típico desasosiego que sigue al incumplimiento de un deber matrimonial (por ejemplo, del de fidelidad o de cohabitación) o la afectación del interés en el mantenimiento del matrimonio y sus beneficios. Como es obvio, la ausencia de anormalidad de las perturbaciones generadas por la infracción de deberes conyugales será más frecuente en caso de crisis matrimonial (sobre todo irreversible), ya que las conductas que en otro contexto se considerarían intolerables, suelen estimarse normales en supuestos de fractura de la vida familiar, por ejemplo, el abandono del hogar marital. Por el contrario, las consecuencias de la vulneración de deberes matrimoniales deberán resarcirse si configuran un delito o falta penal, un atropello a derechos fundamentales o, en general, un menoscabo de magnitud suficiente, como ocurre, v. gr., en los supuestos de violencia intrafamiliar, atentados al honor o la intimidad y ocultación de paternidad. Adicionalmente, considerando que solo son resarcibles las consecuencias directamente vinculadas con la respectiva conducta, no resultará nada sencillo en la mayor parte de los casos probar que las perturbaciones que sufre uno de los cónyuges encuentran su causa inmediata en el incumplimiento de un deber matrimonial, como el de fidelidad o el de cohabitación, principalmente en el marco de una crisis familiar.

b) En cuanto a la culpabilidad, es altamente dificultoso concluir que las consecuencias de la infracción de deberes matrimoniales son atribuibles a una conducta dolosa o negligente, sobre todo en el contexto de una crisis matrimonial. En sentido técnico-jurídico, no resulta sencillo calificar las conductas que generan dichas consecuencias como deliberadas o descuidadas, siendo en extremo difícil afirmar, por ejemplo, que la infidelidad o el abandono de hogar constituyen comportamientos dolosos o negligentes.

Como sea, por lo que atañe al dolo, existe consenso en que todo comportamiento de un cónyuge en que concurra y genere un detrimento de magnitud suficiente y directo en los intereses del otro, debe dar lugar a resarcimiento, como en los supuestos de violencia intrafamiliar.

En cuanto a la culpa, hay que tener en cuenta que al efecto de su configuración deben ponderarse diversos factores, como la falta de diligencia y, conectada con ella, la previsibilidad, que en el ámbito de las relaciones de familia presentan peculiaridades.

Teniendo en cuenta lo anterior, es indiscutible que la imputabilidad debe evaluarse a la luz de las particularidades de las relaciones de familia, así como de la específica dinámica y forma en que habitualmente se 
comportan los individuos en su vida marital. Así, debe considerarse que en este ámbito las personas suelen comportarse de manera muy distinta a como lo hacen en sus relaciones sociales y comerciales, razón por la cual el estándar de conducta que debe servir de parámetro de comparación no ha de ser el que típicamente se tiene a la vista en dichas esferas, en que los individuos se desempeñan de forma menos espontánea, sino uno inferior. Naturalmente, la evaluación culpabilística deberá hacerse con particular celo en el escenario en que mayormente se incumplen los deberes matrimoniales, esto es, en los supuestos de crisis conyugal (sobre todo si es irreversible), en que la forma de comportarse de las personas presenta peculiaridades completamente distintas de las que presenta en otros contextos. Así, como la vulneración de deberes matrimoniales suele materializarse en el marco de una crisis conyugal, en una abundante cantidad de supuestos será en extremo difícil concluir que al infractor le era exigible otra conducta, que debió observar un estándar mayor de diligencia o que el "buen padre" o "madre de familia" habría actuado de forma distinta. La dificultad proviene de que en multitud de ocasiones una conducta de incumplimiento de deberes conyugales puede catalogarse como un comportamiento normal en una situación de crisis matrimonial.

7. Finalmente, existen otros argumentos para negar lugar a la indem134 nización de las consecuencias de la infracción de deberes conyugales. En efecto, la consolidación de una jurisprudencia que la hiciera procedente como regla general podría repercutir en el desincentivo del matrimonio, la obstaculización del divorcio y/o la sobrecarga del aparato jurisdiccional.

\section{Bibliografía CITADA}

Abeliuk Manasevich, René (2014). Las obligaciones, T. I. Santiago: Thomson Reuters.

Acuña San Martín, Marcela (2011). Efectos jurídicos del divorcio. Santiago: Editorial Jurídica de Chile.

Barcia Lehmann, R., y Rivera Restrepo, J. (2015). “iEn qué casos el incumplimiento de deberes del matrimonio genera responsabilidad civil?”. Ius et Praxis. $\mathrm{N}^{\mathrm{o}}$ 2. Talca.

Barrientos Grandon, Javier y Novales AlQuézar, María Aránzazu (2004). Nuevo derecho matrimonial chileno. Santiago: LexisNexis.

Barros Bourie, Enrique (2006). Tratado de responsabilidad extracontractual. Santiago: Editorial Jurídica de Chile.

Bonilla Correa, Jesús (2012). "La responsabilidad civil en los delitos de violencia de género". Revista Aranzadi de Derecho Patrimonial. No 28. Cizur Menor. 
BRAVO Silva, Daniel (2015). "Responsabilidad civil entre cónyuges y excónyuges, por hechos cometidos durante el matrimonio: panorama jurisprudencial en Chile, con especial referencia a la sentencia de la Corte de Apelaciones de La Serena de 3 de abril de 2014”, en Vidal Olivares, Álvaro, Severín Fuster, Gonzalo y Mejías Alonso, Claudia (edits.), Estudios de Derecho Civil X. Jornadas Nacionales de Derecho Civil Valparaíso, 2014. Santiago: Thomson Reuters.

CARrión Olmos, Salvador (2006). "Promesa de matrimonio y resarcimiento de daños". Revista Aranzadi de Derecho Patrimonial. No 17. Cizur Menor.

Casas Becerra, Lidia y Hernández Paulsen, Gabriel (2009). "Familia y sexualidad en el Derecho chileno", en Benítez GonzÁlez, Jorge y Rosas Aravena, Pedro (edits.), La república inconclusa. Una nueva constitución para el bicentenario. Santiago: Editorial Arcis.

Corral Talciani, Hernán (2014). "La incipiente jurisprudencia chilena sobre daños en la familia". Revista de Derecho de Familia. N $^{\circ} 4$. Santiago.

De la Maza Gazmuri, Íñigo (2014). "Plegarias atendidas: procreación asistida y wrongful life actions", en Lepín Molina, Cristián (dir.) y Vargas Aravena, David (coord.), Responsabilidad civil y familia. Santiago: Thomson Reuters.

De verda, Ramón y Chaparro, Pedro (2012). "Responsabilidad civil por incumplimiento de los deberes conyugales". Revista Aranzadi de Derecho Patrimonial. No 28. Cizur Menor.

Domínguez Águila, Ramón y Domínguez Benavente, Ramón (2011). Derecho sucesorio. T. II. Santiago: Editorial Jurídica de Chile.

Ferrer i RibA, Josep (2001). "Relaciones familiares y límites del derecho de daños". Indret. $\mathrm{N}^{\mathrm{O}}$ 4. Barcelona.

Fleitas Ortiz de Rozas, Abel (2001). "Responsabilidad por daños y perjuicios entre cónyuges”. Revista de Derecho de Daños. No 2. Buenos Aires.

Gil Domínguez, Andrés, Fama, María Victoria y Herrera, Marisa (2006). Derecho constitucional de familia. T. I. Buenos Aires: Ediar.

Gómez Calle, Esther (2002). "Responsabilidad de padres y centros docentes", en Reglero Campos, Fernando (coord.). Tratado de responsabilidad civil. Navarra: Aranzadi.

Herane Vives, Francisco (2007). "Reparación por incumplimiento de los deberes matrimoniales", en Corral Talciani, Hernán y Rodríguez Pinto, María Sara, Estudios de Derecho Civil II. Jornadas Nacionales de Derecho Civil Olmue 2006. Santiago: LexisNexis.

Hernández Paulsen, Gabriel (2008). Responsabilidad civil por daños ocasionados en las relaciones de familia. Santiago: Colegio de Abogados.

Hinestrosa Daza, Ricardo (2002). Tratado de las obligaciones, T. I. Bogotá: Universidad Externado de Colombia.

Lepín Molina, Cristián (2014). "Responsabilidad civil en las relaciones de familia”, en Lepín Molina, Cristián (dir.) y Vargas Aravena, David (coord.), Responsabilidad civl y familia. Santiago: Thomson Reuters. 
LÓPEZ DE la CRUZ, Laura (2010). "El resarcimiento del daño moral ocasionado por el incumplimiento de los deberes conyugales". Indret. $\mathrm{N}^{\mathrm{O}} 4$. Barcelona.

Marín García de LeOnardo, Teresa (2006 a). "Aplicación del Derecho de daños al incumplimiento del régimen de visitas". Revista Aranzadi de Derecho Patrimonial. $\mathrm{N}^{\mathrm{O}}$ 17. Cizur Menor.

Marín García de Leonardo, Teresa (2006 b). "Remedios indemnizatorios en el ámbito de las relaciones conyugales". Revista Aranzadi de Derecho Patrimonial. $\mathrm{N}^{\mathrm{O}}$ 17. Cizur Menor.

Martín-Casals, M. y Ribot, J. (2011). "Daños en el derecho de familia: un paso adelante, dos atrás”. Anuario de Derecho Civil. Vol. 64. N 2. Madrid.

Medina, Graciela (2008). Daños en el derecho de familia. $2^{\mathrm{a}}$ ed. actualizada. Buenos Aires: Rubinzal-Culzoni.

Mendoza Alonso, Pamela (2011). "Daños morales por infidelidad matrimonial. Un acercamiento al derecho español". Revista Chilena de Derecho y Ciencia Política. Vol. 2. No 2. Temuco.

Moisset de EsPAnÉs, Luis (2013). Obligaciones naturales y deberes morales. $2^{\mathrm{a}}$. ed. Bogotá: Pontificia Universidad Javeriana.

Novales Alquézar, María Aránzazu (2007). Los deberes personales entre los cónyuges ayer y hoy. Granada: Comares.

Novales Alquézar, María Aránzazu (s/a). Responsabilidades especiales. ¿De136 bería haber en el Derecho Matrimonial mecanismos reparatorios?, en AA. VV., Cuadernos de Análisis Jurídico IV. Regímenes especiales de responsabilidad civil. Santiago: Universidad Diego Portales.

Opazo GonzÁlez, Mario (2012). "El principio de la reparación integral del daño y los daños causados por adulterio”, en ELORRIAGA DE BONIS, Fabián (coord.), Estudios de Derecho Civil VII. Jornadas Nacionales de Derecho Civil Viña del Mar, 2011. Santiago: Thomson Reuters.

OtÁrola Espinosa, Yasna (2014). "La naturaleza obligacional de los deberes matrimoniales", en Turner Saelzer, Susan y Varas Braun, Juan Andrés (coords.), Estudios de Derecho Civil X. Jornadas Nacionales de Derecho Civil Valdivia 2013. Santiago: Thomson Reuters.

Pizarro Wilson, Carlos (2014). "Responsabilidad civil por no reconocimiento voluntario del hijo de filiación extramatrimonial”, en LePín MolinA, Cristián (dir.) y Vargas Aravena, David (coord.), Responsabilidad civil y familia. Santiago: Thomson Reuters.

Ramos Cabanellas, Beatriz (2014). "Daños originados en las relaciones de familia”, en Lepín Molina, Cristián (dir.) y Vargas Aravena, David (coord.), Responsabilidad civil y familia. Santiago: Thomson Reuters.

Ramos Pazos, René (2005). Derecho de familia, T. I. $5^{\text {a }}$. ed. actualizada. Santiago: Editorial Jurídica de Chile.

Roca TríAs, Encarna (2000). "La responsabilidad civil en el derecho de familia. Venturas y desventuras de cónyuges, padres e hijos en el mundo de la res- 
ponsabilidad civil”, en Moreno Martínez, Juan Antonio (coord.), Perfiles de la responsabilidad civil en el nuevo milenio. Madrid: Dykinson.

Romero Coloma, María Aurelia (2009). Reclamaciones e indemnizaciones entre familiares en el marco de la responsabilidad civil. Barcelona: Bosch.

Sáinz-Cantero, M. B. y PÉrez, A. M. (2012). Valoración y reparación de daños entre familiares. Fundamentos para su reparación. Granada: Comares.

Sambrizzi, Eduardo (2001). Daños en el derecho de familia. Buenos Aires: La Ley.

Severín Fuster, Gonzalo (2008 a). "Indemnización entre cónyuges por los daños causados con ocasión del divorcio", en GuZMÁn Brito, Alejandro (ed. científico), Estudios de Derecho Civil III. Jornadas Nacionales de Derecho Civil Valparaíso, 2007. Santiago: LegalPublishing.

Severín Fuster, Gonzalo (2008 b). "Demandas de daños en los tribunales de familia. Comentarios a un fallo, a partir de la modificación introducida por la ley 20.286 en materia de competencia del tribunal". Nomos. $\mathrm{N}^{\mathrm{o}} 2$.

Somarriva Undurraga, Manuel (2008). Derecho sucesorio. T. I. Santiago: Editorial Jurídica de Chile.

Tapia Rodriguez, Mauricio (2016). "Contra la indemnización de perjuicios por incumplimiento de deberes conyugales”, en Lepín Molina, Cristián y GóMEZ DE la TORRe Vargas, Maricruz (coords.), Estudios de derecho familiar I. Santiago: Thomson Reuters.

Turner Saelzer, Susan (2013). "Deberes personales derivados del matrimonio y daños en la jurisprudencia chilena”, en Domínguez Hidalgo, Carmen, González Castillo, Joel, Barrientos Zamorano, Marcelo y Goldenberg SerRano, Juan Luis (coords.), Estudios de Derecho Civil VIII. Jornadas Nacionales de Derecho Civil Santa Cruz, 2012. Santiago: Thomson Reuters.

Valenzuela del Valle, Jimena (2012). "Responsabilidad civil por el incumplimiento de obligaciones matrimoniales y por el ejercicio abusivo del divorcio unilateral. Un estudio de su admisibilidad en Chile". Revista de Derecho Universidad Católica del Norte. $\mathbf{N}^{\mathbf{0}} 1$. Coquimbo.

Vargas Arvena, David (2009). Daños civiles en el matrimonio. Madrid: La Ley.

Vargas Arvena, David (2014). "Responsabilidad civil en el ámbito matrimonial según la jurisprudencia chilena". Actualidad Jurídica Iberoamericana. $\mathrm{N}^{\mathrm{O}} 1$. Valencia.

Vicente Domingo, Elena (2002). "El Daño", en Reglero Campos, Fernando (coord.), Tratado de responsabilidad civil. Navarra: Aranzadi.

ZAikoski BISCAY, Daniela (2015). "Responsabilidad civil y violencia contra las mujeres. Aproximaciones desde la perspectiva sociojurídica". Derecho de Familia. Revista Interdisciplinaria de Doctrina y Jurisprudencia. No 69 . Buenos Aires.

Zambrano, Virginia (2014). "Responsabilidad civil en el entorno familiar", en Lepín Molina, Cristián (dir.) y Vargas Aravena, David (coord.), Responsabilidad civil y familia. Santiago: Thomson Reuters. 


\section{Normas citadas}

\section{Código Civil.}

Código Penal.

Ley $N^{\circ}$ 20.830, Crea el Acuerdo de Unión Civil. Diario Oficial, 21 de abril de 2015.

Ley $\mathrm{N}^{\mathrm{o}} 20.066$, Establece Ley de Violencia Intrafamiliar. Diario Oficial, 7 de octubre de 2005.

Ley No 19.968, Crea los Tribunales de Familia. Diario Oficial, 30 de agosto de 2004.

Ley No 19.947, Establece Nueva Ley de Matrimonio Civil. Diario Oficial, 17 de mayo de 2004.

\section{Jurisprudencia citada}

Magdalena Fuentes Bustos con Edilio Palma Rivera (2016): Corte de Apelaciones de Chillán, 16 de junio de 2016 (apelación), VLEX-643721133.

Marcelo de la Huerta Castellón con José Cabezas Muñoz y Pamela Salcedo Torres (2016): Corte de Apelaciones de Santiago, 22 de marzo de 2016 (apelación), VLEX-644182693.

María Marín Suárez con José Valenzuela Guiraldes (2015): Corte Suprema, 11 de marzo de 2015 (casación en el fondo), VLEX-560733522.

Javiera Moraga Ruíz con Alberto Cazes Oviedo (2015): Corte Suprema, 12 de enero de 2015 (casación en el fondo), VLEX-552427706.

Zunilda Pinto Carmona con Víctor Rojas Núñez (2014): Corte Suprema, 30 de diciembre de 2014 (casación en el fondo), VLEX-550944278.

Javiera Moraga Ruíz con Alberto Cazes Oviedo (2014): Corte de Apelaciones de Santiago, 21 de agosto de 2014 (apelación), VLEX-571484014.

Zunilda Pinto Carmona con Víctor Rojas Núñez (2014): Corte de Apelaciones de la Serena, 3 de abril de 2014 (apelación), VLEX-641005201.

Luisa Abarca González con Pedro González Leyton (2012): Corte Suprema, 2 de julio de 2013 (casación en el fondo), VLEX-473105646.

Alexandra Riddel Haack con Pablo Albornoz Sateler (2012): Corte Suprema (casación en la forma y casación el fondo), 28 de septiembre de 2012, VLEX436785398.

Luisa Abarca González con Pedro González Leyton (2012): Corte de Apelaciones de Talca, 31 de agosto de 2012 (apelación), VLEX-400958090.

Ricardo Prado Cuevas con Bernardita Alcalde Ochagavía y otro (2012): Corte Suprema, 13 de julio de 2012 (casación en el fondo), Legal Publishing CL/ JUR/1094/2012.

Félix Niklitsckeck Strauch con María Rosas Loebel (2012): Corte Suprema, 6 de marzo de 2012 (casación en el fondo), VLEX-436244906. 
Aurelia Soto Mesa con Patricio González Oliva (2011): Corte Suprema, 14 de octubre de 2011 (casación en el fondo), Legal Publishing CL/JUR/8275/2011.

Félix Niklitsckeck Strauch con María Rosas Loebel (2010): Corte de Apelaciones de Puerto Montt, 20 de diciembre de 2010 (casación en la forma y apelación), www.poderjudicial.cl.

Andrea Cerón Briso con Pablo Quezada Valderrama (2010): Corte de Apelaciones de Santiago (apelación), 4 de noviembre de 2010, VLEX-233697275.

Alexandra Riddel Haack con Pablo Albornoz Sateler (2010): Corte de Apelaciones de Santiago (casación en la forma y apelación), 13 de julio de 2010, www.poderjudicial.cl.

Ricardo Prado Cuevas con Bernardita Alcalde Ochagavía y otro (2009): Corte de Apelaciones de Santiago, 10 de noviembre de 2009 (apelación), MJCH_ MJJ22318.

Cristián Barrios Riedel con Virginia Espinosa Vallejos (2008): Corte Suprema, 17 de diciembre de 2008 (casación en el fondo), VLEX-55547529.

Claudio Peñaloza González con Olga Hebles Melo (2008): Corte de Apelaciones de Concepción, 15 de septiembre de 2008 (apelación), www.centrodefamiliauc.cl.

F. M., H. con V. C., M. (2007): Corte de Apelaciones de Rancagua, 29 de octubre de 2007 (apelación), Lexis Nexis 38473. 